\title{
The Role of Macrophytes in Constructed Surface-flow Wetlands for Mine Water Treatment: A Review
}

\author{
Joscha Opitz ${ }^{1,2} \cdot$ Matthias Alte $^{2} \cdot$ Martin Bauer $^{2} \cdot$ Stefan Peiffer $^{1}$
}

Received: 16 August 2020 / Accepted: 1 April 2021 / Published online: 20 April 2021

(c) The Author(s) 2021

\begin{abstract}
Constructed wetlands are a standard sustainable technology in waste and mine water treatment. Whereas macrophytes actively contribute to decomposition and/or removal of wastewater's organic pollutants, removal of hydrolysable metals from mine water is not attributable to direct metabolic, but rather various indirect macrophyte-related mechanisms. These mechanisms result in higher treatment efficiency of (vegetated) wetlands relative to (unvegetated) settling ponds. Contribution of macrophytes to treatment predominantly includes: enhanced biogeochemical oxidation and precipitation of hydrolysable metals due to catalytic reactions and bacterial activity, particularly on immersed macrophyte surfaces; physical filtration of suspended hydrous ferric oxides by dense wetland vegetation down to colloids that are unlikely to gravitationally settle efficiently; scavenging and heteroaggregation of dissolved and colloidal iron, respectively, by plant-derived natural organic matter; and improved hydrodynamics and hydraulic efficiency, considerably augmenting retention and exposure time. The review shows that constructed surface-flow wetlands have considerable advantages that are often underestimated. In addition to treatment enhancement, there are socio-environmental benefits such as aesthetic appearance, biotope/habitat value, and landscape diversity that need to be considered. However, there is currently no quantitative, transferrable approach to adequately describe the effect and magnitude of macrophyte-related benefits on mine water amelioration, let alone clearly assign optimal operational deployment of either settling ponds or wetlands. A better (quantitative) understanding of underlying processes and kinetics is needed to optimise assembly and sizing of settling ponds and wetlands in composite passive mine water treatment systems.
\end{abstract}

Keywords Passive treatment $\cdot$ Filtration $\cdot$ Biogeochemistry $\cdot$ Settling pond $\cdot$ Hydrodynamics

\section{Introduction}

Constructing wetlands for treatment of municipal, domestic, agricultural, and industrial wastewater dates back to the early 1950s (Seidel 1966; Vymazal 2014). In the late 1970s and early 1980s, observation of positive effects of natural wetlands on mine drainage chemistry in the Appalachian coalfields led to adaptation of wetlands for treatment of acidic and/or metalliferous mine water (Huntsman et al. 1978; Wieder 1989). Nowadays, constructed wetlands are used to passively remove a variety of mine water contaminants,

Joscha Opitz

joscha.opitz@uni-bayreuth.de

1 Department of Hydrology, University of Bayreuth, Universitätsstraße 30, 95447 Bayreuth, Germany

2 Base Technologies GmbH, Josef-Felder-Straße 53, 81241 Munich, Germany predominantly hydrolysable metals (Al, Fe, Mn), but also other metals typically associated with mining activities (Ag, $\mathrm{Cd}, \mathrm{Co}, \mathrm{Cr}, \mathrm{Cu}, \mathrm{Hg}$, $\mathrm{Mo}, \mathrm{Ni}, \mathrm{Pb}, \mathrm{U}, \mathrm{V}, \mathrm{Zn}$ ), metalloids (e.g., $\mathrm{As}, \mathrm{Sb}, \mathrm{Se}$ ), and other pollutants (e.g., cyanide, ammonia) (e.g., Noller et al. 1994; Pedescoll et al. 2015; Sobolewski 1999; Walton-Day 1997). Since then, application of mine water treatment wetlands has been spreading worldwide, with a focus on legacy mine sites.

Both aerobic (free water surface-flow) and anaerobic (vertical/subsurface-flow) wetlands as well as composite systems are used for passive mine water treatment according to mine discharge chemistry. Anaerobic wetlands are primarily used to treat acidic mine drainage (AMD) by way of alkalinity generation and metal sulphide precipitation, whereas aerobic wetlands are used to treat neutral, metalliferous mine drainage by way of oxidation and precipitation of hydrolysable metals (Skousen et al. 2017). This study is focussed on 
aerobic surface-flow wetlands (hereinafter "wetlands"), with macrophytes prevalent in the free water column.

It is generally hypothesised that macrophytes have a considerable effect on treatment performance and are the keystone of surface-flow wetlands, which are in turn the key "polishing" component to achieve a specific compliance target for most passive treatment systems (Batty 2003; Batty and Younger 2002). The importance of macrophytes is undebated for wastewater treatment wetlands, where plants actively participate in central elemental cycles $(\mathrm{C}, \mathrm{N}, \mathrm{P})$ and release allelochemicals or antibacterial substances (Bavor et al. 2001; Kadlec and Wallace 2009; Vymazal 2014). Ample literature based on quantitative studies exists on the design and sizing of wetlands for wastewater treatment (e.g., Kadlec and Wallace 2009; Kadlec et al. 2000; Pedescoll et al. 2015).

In contrast, there has been a long-standing discussion whether mine water treatment wetlands outperform unvegetated settling ponds, since macrophytes do not take a metabolically active role in metal removal. With numerous studies indicating better treatment performance and hydraulic efficiency for wetlands compared to settling ponds, recently including direct juxtaposition of large data sets (e.g., Opitz et al. 2019; Pedescoll et al. 2015; Sapsford 2013; Sapsford and Watson 2011), there is general agreement that wetlands are superior in terms of treatment efficiency, particularly for low iron concentrations (Batty et al. 2008). It was consequentially concluded that, beyond the aesthetic value, macrophytes play an important role even without substantial direct uptake of hydrolysable metals or metabolic effects on metal removal mechanisms (Batty 2003; Brix 1994; Sheoran and Sheoran 2006). For instance, some aspects, such as improved hydrodynamics and floc filtration by macrophytes are frequently quoted (Skousen et al. 2017), and Batty and Younger (2002) even showed that metal uptake may be a factor at residual iron concentrations. However, to this day, the processes and effects bringing about superior metal removal efficiency in wetlands are described rather vaguely, particularly from a quantitative perspective (Johnson and Hallberg 2002). In addition, there is still an ongoing discussion whether better treatment performance justifies increased operation and maintenance requirements, shorter refurbishment cycles, and complicated disposal of both metalliferous and organic-rich sediments.

A holistic view of core advantages and disadvantages as well as underlying processes and effects of wetlands is required to facilitate well-founded decisions regarding the deployment of vegetated or unvegetated ponds, both as stand-alone units and in composite passive systems (Sapsford 2013). In this context, it stands to reason that macrophytes are the decisive difference between wetlands and settling ponds. The purpose of this study is to give a literature-based overview of the current state of knowledge regarding the contribution of macrophytes to mine water amelioration in surface-flow wetlands. The goal is to identify and describe the determining macrophyte-related processes and effects contributing to mine water contaminant removal as a (qualitative) basis for future in-depth investigation and quantification of these effects. A better understanding of macrophyte-related effects would go a long way towards circumscribing or parameterising the difference between settling ponds and wetlands and to ultimately improving the design and sizing of composite passive systems. Exemplary hydrochemical and environmental juxtaposition of settling ponds and wetlands in this study is provided from international literature and a closely monitored passive pilot plant featuring equally sized, consecutive settling ponds and wetlands, as described in Opitz et al. (2019, 2020).

\section{Ecological Background}

Treatment wetlands are designed to artificially emulate natural wetlands, creating a near-natural and densely vegetated aquatic environment. Wetlands are exceptional in that various transitional and sometimes opposed environmental conditions (e.g., stagnant to flowing, clear to turbid, oligotrophic to eutrophic) and gradients (e.g., temperature, $\mathrm{pH}$, oxygenation, light exposure, redox potential) are found in a spatially confined area and may display considerable temporal (e.g., diurnal, seasonal, or hydrological cycles) variation (Bezbaruah and Zhang 2004; Feierabend 1989; García et al. 2003; Kadlec and Wallace 2009). Wetlands are exceedingly dynamic systems that generally display substantial biomass production and mineralisation, thus supporting intensive substance and nutrient cycles (Mitsch et al. 2012). Consequently, wetlands are a hotspot of (micro)biological activity and productivity, usually supporting a particularly vibrant and diverse ecosystem. It is therefore hardly surprising that wetland biogeochemistry also affects metal (redox) cycles and transformations with demonstrably positive effects on water quality (Fennessy and Mitsch 1989; Sobolewski 1999; Wildemann et al. 1993).

According to Kadlec et al. (2000), macrophytes are "the dominant structural component of most wetland treatment systems." Early field observations and trials of shallow Sphagnum bogs showed promising metal removal capacities, especially for mildly acidic and neutral mine water (Kleinmann et al. 1983; Wieder et al. 1982). However, overall and especially long-term performance of hybrid Sphagnum bogs was rather variable due to progressive armouring of the plants, especially when faced with acidic and/or highly ferruginous loadings (Brenner et al. 1993; Henrot and Wieder 1990). To further augment metal removal and alkalinisation, early mine water treatment wetlands were soon being constructed as hybrid marsh-like wetlands with low water 
depth $(5-25 \mathrm{~cm})$ and high substrate depth $(\approx 50 \mathrm{~cm})$ to facilitate both open water and pore space flow with limestoneamended organic or peat substrates for metal adsorption and alkalinity generation (Girts et al. 1987; Wieder 1989). Eventually, this led to the more targeted forking into anaerobic and aerobic wetlands seen today (Hedin et al. 1994; McIntire and Edenborn 1990). Nowadays, aerobic wetlands are constructed as shallow basins with a loose rooting substrate predominantly planted with emergent, tall-growing herbaceous macrophytes, although submerged or floating plants may occur alongside. Recommendations for water depths range from $15-25 \mathrm{~cm}$ (Younger et al. 2002) to $10-50 \mathrm{~cm}$ (Hedin et al. 1994). Generally, a water depth of $50 \mathrm{~cm}$ was reported as the maximum tolerable by emergent, tall-growing macrophytes, e.g. Typha and Phragmites generas, to reliably develop dense vegetation coverage (Brodie 1991; Wildemann et al. 1993). However, most wetlands are designed with water depths of $10-40 \mathrm{~cm}$ to promote vegetation diversity and to accommodate other hygrophilous plants from generas such as Juncus, Scirpus/Schoenoplectus, Carex, Acorus, Eleocharis, and Sphagnum. Planting of constructed wetlands is guided by environmental conditions and local species, with, for instance, Phalaris or Cyperus preferred in warm, subtropical or tropical climates. Plant community in constructed wetlands may display considerable floral diversity, although over time, dominance of fast-growing reeds and cattails is to be expected in temperate climates due to their environmental resilience, competitive vegetative growth, and reproduction (Brodie 1991; Maine et al. 2009; Stark et al. 1994). Population density varies depending on water level, water quality, plant community, and climate, yet may quickly reach up to several dozen cattails (Sencindiver and Bhumbla 1988; Stark et al. 1994) or several hundred reed shoots per $\mathrm{m}^{2}$ (Tanner 1996).

Due to the dynamic environmental conditions of wetlands, respective macrophytes are adapted to or tolerate chemical and biophysical stress. Hence, most wetland plants are robust towards the detrimental or even potentially toxic conditions that are characteristic for both acidic and metalliferous mine drainage, including but not limited to low $\mathrm{pH}$, high pollutant levels (metals, metalloids, sulphate, ammonia), high levels of dissolved and/or suspended solids, increased salinity and turbidity (the latter also reducing light transition), and low dissolved oxygen and nutrient levels (e.g., Batty and Younger 2003; Karathanasis and Johnson 2003; Manios et al. 2003; Nixdorf et al. 2001; Tanner 1996; Taylor and Crowder 1983; Wu et al. 2015) as well as ochre plaque on plants, roots, and rooting soil (e.g., Chabbi 1999; Fernandes and Henriques 1990; Snowden and Wheeler 1995). Respective tolerance or phytotoxicity thresholds as well as uptake capacity and bioaccumulation were observed to be high in wetland macrophytes, both towards surrounding water and rooting substrate or soil solution (e.g., Batty and Younger 2003; Maine et al. 2006; Matthews et al. 2004; Outridge and Noller 1991; Ye et al. 1997b). Although impairment of both physiological development and nutrient metabolism were observed for macrophytes in mining influenced waters by Batty and Younger $(2003,2004)$ and Wenerick et al. (1989), most treatment wetlands achieve full vegetation cover within a few years, even under at times life-hostile conditions (Mayes et al. 2009; Stark et al. 1994).

\section{Contributing Processes and Aspects}

The following review of the various effects of macrophytes on mine water treatment in wetlands is sorted by the nature of the process or effect as much as possible. Where overlap is intrinsic, assignment was done to the best of our judgement. Most effects are related to iron removal as the principal treatment goal in surface-flow mine water treatment wetlands.

\section{Filtration Effects}

Submerged parts of aquatic macrophytes such as shoots, leaves, rhizomes, and roots as well as fresh litter and decaying detritus provide substantial surface area for particle filtration through interception and trapping of suspended solids. Various field and laboratory studies have shown significantly increased particulate matter retention in vegetated compared to unvegetated flowing waters (e.g. Cotton et al. 2006; Elliot 2000; Horvath 2004; Pluntke and Kozerski 2003; Saiers et al. 2003; Verschoren et al. 2017). Most studies were able to pinpoint macrophytes as the ultimate cause. For example, Verschoren et al. (2017) compared a lowland river reach in fully vegetated (77-90\% cover), partly mown ( $48-56 \%$ cover) and unvegetated ( $0 \%$ cover) state and found an increase in mean particle travel distance (e.g., 14.0 vs. 15.4 vs. $25.4 \mathrm{~m}$ for wood chips) as well as a decrease in particle retention (e.g., 97.2 vs. 96.1 vs. $86.0 \%$ for wood chips) and hydraulic efficiency $(0.83 \pm 0.03$ vs. $0.76 \pm 0.03$ vs. $0.67 \pm 0.03$ for $\mathrm{NaCl}$ tracer tests) with progressing vegetation removal. Analogously, Pluntke and Kozerski (2003) observed approximate doubling of particle retention in vegetated compared to unvegetated experimental littoral conditions using particles and spores in the size range of 3-120 $\mu \mathrm{m}$. What is more, Saiers et al. (2003) found increasing removal of colloidal $\mathrm{TiO}_{2}$ (average diameter $0.3 \mu \mathrm{m}$ ) in a surface-water flume facility vegetated with Eleocharis spp. and estimated that " $a$ single stem was capable of scavenging $29 \%$ of the particles that approached its projected cross-sectional area from the upstream direction”. Consequently, macrophyte-related 
filtration of particulate matter is not limited to macroflocs in the upper micrometre range that are predestined to gravitationally settle quickly according to the ratio of flow and settling velocity (Sheoran and Sheoran 2006), but also affects dispersed nanoparticles and colloids that are not susceptible to effective gravitational sedimentation and would thus pass through settling ponds unimpeded. Fennessey and Mitsch (1989) observed a significant increase in particulate iron removal rates from mine water, from $20-30 \%$ before up to $50-60 \%$ after full development and maturation of cattail populations. Interestingly, the authors also positively correlated iron removal and Typha biomass production in the three consecutive wetland cells, although the relationship may be affected by differences in influent water chemistry.

Generally, particle interception increases with increasing vegetation cover. Therefore, existing approaches to quantification of improved particle retention by dense aquatic vegetation are often based on or include respective physical, plant-related parameters (e.g., immersed surface area, stalk diameter, plant density, biomass) and ecological factors (e.g., plant species, vegetation development; e.g., Nepf 1999; Saiers et al. 2003; Schmid et al. 2005; Verschoren et al. 2017). Since filtration of suspended particles by macrophytes was also observed to be influenced by hydrodynamics (e.g., flow velocity, velocity distribution, shear stress) and particle characteristics (e.g., concentration, size, morphology, or charge), further approaches to quantification of particle retention by wetland macrophytes are based on modelling of particle-macrophyte interaction at laminar flow related to, for example, plant-related alteration in velocity distribution, turbulence, shear velocity, and drag. Most models and relationships are, however, based on specific assumptions or site-specific, empirical wetland and particle characteristics, respectively. Since wetlands are very diverse and dynamic systems and the examined particles are a variety of organic and inorganic materials that are easy to handle and reasonably representative of natural waterborne particles (e.g., polymers, spores, chips, clay, corundum, quartz), findings from existing studies are hardly transferrable to mining environments. In this context, periphyton coating of macrophytes may considerably alter colloid filtration, depending on the particle surface charge, as speculated by Saiers et al. (2003). Unfortunately, the authors of this study know of no (quantitative and transferrable) results regarding increased removal of hydrous ferric oxides by macrophytes in mine water treatment wetlands to date.

\section{Physico-chemical Effects}

Plant surfaces in general, and ochre-covered tissues in particular, provide extensive catalytic surfaces for adsorption, heterogeneous oxidation, and precipitation of dissolved (supersaturated) metals (Batty et al. 2008). Reactive surfaces greatly increase reaction kinetics and thus accelerate removal of divalent iron and manganese from mine waters (Dempsey et al. 2001). Heterogeneous ferrous iron oxidation is assumed to be either closely linked to or in competition with biological oxidation (van der Beek et al. 2012), although the borderline or interrelation between surfacecatalysed (chemical) and bacterially-catalysed (biological) ferrous iron oxidation as well as between inorganic plaque and biofilms in circumneutral aquatic environments is still unclear and the subject of current research. Similar uncertainties are found in the field of drinking water purification (Mouchet 1992; van Beek et al. 2012). Irrespective of this discussion, oxidation of divalent iron and manganese ions is clearly expected to increase in the presence of reactive surfaces and/or respective iron-oxidising bacteria (Batty et al. 2008; Luan et al. 2012) and it is well-known that other metals associated with mine waters are susceptible to sorption on submerged macrophyte surfaces, as reported by Lesage et al. (2007). Ochreous surfaces and biofilms are most important at low or residual iron concentrations where hydrous ferric oxides (and the catalytic effect they can provide) are negligible.

\section{Biochemical Effects}

In the context of this study, biological and biochemical effects describe a passive or indirect contribution by wetland macrophytes to metal transformation or removal that does not (directly) involve the plant's intrinsic metabolism.

First and foremost, the near-natural aquatic and benthic environment created by hydrophytes with at times steep gradients in dissolved oxygen, redox potential, and $\mathrm{pH}$ favours development of microorganisms benefiting from environmental heterogeneity. Roots and submerged plant tissue as well as root exudations provide a suitable, nurturing environment and growth surface for development of extensive biofilms and periphyton, and generally stimulate bacterial activity and diversity (Dunbabin and Bowmer 1992; Pietrangelo et al. 2018; Weiss et al. 2003). Field observations of mining-influenced waters indicate that macrophytes stimulate biogeochemical activity in the water column, rhizosphere, and sediment, including but not limited to biological metal oxidation and subsequent precipitation of respective (hydr)oxides (especially the iron redox-cycle) as well as trace metal assimilation and sequestration (e.g., Chabbi 1999; Doyle and Otte 1997; Emerson et al. 1999; Hansel et al. 2001; Neubauer et al. 2002). Moreover, bacteria can also increase particle flocculation due to particle bridging by way of secreted extracellular polymeric fibres (Banfield et al. 2000; Droppo and Ongley 1994). Ferrous iron oxidation and concomitant precipitation and removal of hydrous 
ferric oxides in passive system was evaluated by way of a performance index $(\varepsilon)$, comparing observed with anticipated ideal iron removal via respective first-order kinetics by Sapsford and Watson (2011). With $\varepsilon=1$ indicating ideal performance, the results showed that iron removal in wetlands lived up to expectations (median $\varepsilon \approx 0.89, \mathrm{n}=12$ ), whereas settling ponds broadly underperformed (median $\varepsilon \approx 0.59$, $\mathrm{n}=10$ ), indicating "that lagoons are less efficient for iron removal than wetlands" (Sapsford and Watson 2011). This is in accordance with the findings of Kadlec (2003), who reported larger removal rate constants for typical wastewater contaminants (TSS, BOD, $\mathrm{NH}_{4}-\mathrm{N}, \mathrm{P}_{\text {tot }}$, fecal coliforms) without exception in unvegetated ponds, attributable to various biogeochemical processes in addition to filtration.

On top of that, field studies indicate a similar, potentially even stronger effect for manganese oxidation. Chemical $\mathrm{Mn}$ (II)-oxidation is kinetically limited at $\mathrm{pH}<8$ and in the presence of ferrous iron, yet may increase in wetlands compared to settling ponds after lowering iron concentrations, as observed by Stark et al. (1995) and Wildemann et al. (1993). The effect is illustrated for the exemplifying pilot system in Fig. 1, with wetlands showing similar (Fe) or better $(\mathrm{Mn})$ removal efficiency than settling ponds despite lower inflow concentrations. Stimulation of metal oxidation processes in wetlands may enhance overall metal removal kinetics, yet the effect of macrophytes on both/either heterogeneous (physico-chemical) and/or bacterial (biological) oxidation is yet to be elucidated.

Current and future research on biological ferrous iron oxidation by neutrophilic bacteria may show if and how chemical and biological oxidation are coupled in circumneutral environments (Emerson and de Vet 2015; Ilbert and Bonnefoy 2013; Kappler et al. 2015), although ferruginous mine waters may pose an additional challenge. At the current state of science, it must be assumed that ferrous iron oxidation in circumneutral mine waters is predominantly driven by chemical oxidation mechanisms (Kirby et al. 1999). Notwithstanding this, bacteria not only contribute to short-term formation of transient amorphous or hydrous metal oxide phases, but also to subsequent long-term transformation to more stable, increasingly crystalline minerals (Tuhela et al. 1992). Beyond that, it is conceivable that biological oxidation of divalent iron and manganese may be increasingly important at more acidic $\mathrm{pH}$ and/or low oxygen concentrations (Kirby et al. 1999; Sobolev and Roden 2001), for residual concentration levels in the compliance range (Batty and Younger 2002; Batty et al. 2008) and in the presence of adequate biofilm growth surfaces (Mouchet 1992; van Beek et al. 2012; Weber et al. 2006).

Furthermore, the generation of dissolved, colloidal, and particulate natural organic matter (NOM) in wetland environments is important for metal cycles and removal due to their affinity for metals and complex organic molecules. The abundance of organic substances in wetlands contributes to further decreases in residual ferrous and ferric iron concentrations in different ways:

First, heteroaggregation of suspended NOM and hydrous ferric oxides was identified as a major iron removal mechanism in estuarine and wetland environments (Mayer 1982; Tipping and Cooke 1982; Tipping and Ohnstad 1984). Put simply, at circumneutral $\mathrm{pH}$, humic substances are negatively charged due to ionisation of carboxyl groups, whereas hydrous ferric oxides are positively charged due to hydrolytic reactions. Consequently, charge neutralisation is achieved by adsorptive aggregation of hydrous ferric oxides and humic substances, resulting in increased aggregate size, stability, and altered zeta potential (Liang et al. 1993). Organic colloids or particles may therefore act as "natural coagulants" for dissolved and suspended iron and enhance formation of larger aggregates that gravitationally settle more easily (Pizarro et al. 1995; Sholkovitz 1978). Iron removal in connection with NOM is particularly important for low or residual iron concentrations, which is not to be underestimated in the context of strict compliance limits (Opitz et al. 2019).

Second, decomposition of plant tissue and detritus releases organic (poly)ligands such as humic and fulvic acids. These anionic groups contribute to scavenging of dissolved iron through organic complexation, sorption, and chelation (Peiffer et al. 1999; Tipping and Hurley 1992). Studies show that organic matter decomposition over time exposes additional ligands and functional groups, resulting in (relative) accumulation und stable immobilisation of iron and other metals within and near the organic-interspersed wetland sediment (Larsen and Schierup 1981; Sobolewski 1999). The potential for remobilisation towards the water phase is considered small since metals are usually bound in stable metal-chelate complexes (Galletti et al. 2010; Sobolewski 1999).

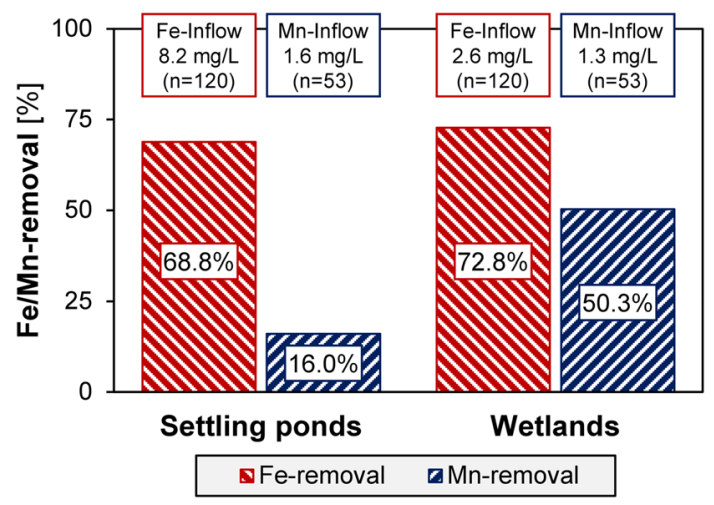

Fig. 1 Relative ferric iron and manganese removal (inflow=100\%) in consecutive settling ponds and wetlands from the pilot system described in Opitz et al. (2019) 
Third, organic matter generated by plant growth and decay is used as an energy source by various microorganisms that contribute to metal transformation and fixation in the aqueous and particularly the benthic zone (Hansel et al. 2001). As a consequence, iron and other metals from soil-solution are precipitated as sulphide minerals in deeper reaches of the sediment and substrate. This metal removal mechanism based on dissimilatory sulphate reduction is, however, characteristic of anaerobic wetlands and covers only a small share of the overall iron load in aerobic wetlands. Nevertheless, the process may be important for polishing and even more so for the removal of trace metals such as $\mathrm{Cu}, \mathrm{Pb}$ and $\mathrm{Zn}$ (Sobolewski 1999).

\section{Phytologic Effects}

Besides the indirect effects described above, macrophytes also actively contribute to mine water treatment and quality by way of several intrinsic phytologic processes and characteristics. Plants are used in environmental remediation for accumulation of contaminants and metals through direct uptake and incorporation into plant tissues (phytoextraction) (Ernst 1996; Khalid et al. 2017). With regard to mine waters, it was firmly established that bioaccumulation of major contaminants such as $\mathrm{Fe}, \mathrm{Al}$, and $\mathrm{Mn}$ in wetlands is negligible at high loadings, for example accounting for less than $1 \%$ of overall iron removal (Fernandes and Henriques 1990; Mitsch and Wise 1998; Sencindiver and Bhumbla 1988). The same is true for other metals associated with mining activities present at noteworthy loadings such as $\mathrm{Cd}, \mathrm{Cr}, \mathrm{Cu}$, $\mathrm{Ni}, \mathrm{Pb}$, and Zn (Liu et al. 2007; Mays and Edwards 2001; Nyquist and Greger 2009) as well as U (Overall and Parry 2004). For example, Ye et al. (2001b) found low accumulation of Fe $(0.91 \%)$, Co $(0.19 \%)$, and $\mathrm{Ni}(0.38 \%)$ in Typha latifolia, despite relatively low loadings and good overall removal throughout the wetland system, indicating that metals were removed by other means than bioaccumulation. It is, however, important to note that numbers on metal uptake in wetlands are generally difficult to compare and sometimes conflicting due to the different (e.g., lab vs. field, metal loading, $\mathrm{pH}$, redox potential, contact time) testing conditions (Marchand et al. 2010).

Nevertheless, many field and mesocosm studies of mine and waste water treatment wetlands indicate that active bioaccumulation by hydrophytes might be relevant for metals at trace concentration levels (e.g., Dunbabin and Bowmer 1992; Ellis et al. 1994; Maine et al. 2006; Outridge and Noller 1991; Schierup and Larsen 1981; Scholes et al. 1998; Ye et al. 1997b). By way of example, Maine et al. (2006) found root tissue metal concentrations of $T$. domingensis to multiply by factors of about $7(\mathrm{Cr})$ and 8 (Ni) at low mean water concentrations (22 and $17 \mu \mathrm{g} / \mathrm{L}$, respectively) within a year of wetland operation, and even a doubling of $\mathrm{Zn}$, despite water concentrations below detection limit $(<0.05 \mu \mathrm{g} / \mathrm{L})$. Perhaps most interestingly, Batty and Younger (2002) reported a maximal iron uptake by $P$. australis seedlings in laboratory exposure experiments of $\approx 100 \%$ at an iron supply of $1 \mathrm{mg} / \mathrm{L}$, dropping at both higher and lower iron concentrations, with $<50 \%$ at 0.5 and $2 \mathrm{mg} / \mathrm{L}$, and $<25 \%$ at $<0.1$ and $\geq 5 \mathrm{mg} / \mathrm{L}$. Metal uptake-including iron-by macrophytes in terms of mass content was shown to increase at greater concentrations (Batty and Younger 2003) — and decrease with increasing water column or flow velocity, presumably due to declining contact time between contaminated water and plant (roots) (Kumari and Tripathi 2015; Schierup and Larsen 1981; Stark et al. 1996). For instance, iron contents in shoots, rhizomes, and roots of up to almost 1, 10, and $100 \mathrm{~g} / \mathrm{kg}$ dry weight, respectively, were observed at solution concentrations of $50 \mathrm{mg} / \mathrm{L}$ in the $P$. australis seedling exposure experiments by Batty and Younger (2003) mentioned above. It was also shown that wetland macrophytes accumulate different metals in different plant components, with the highest concentrations usually found in roots and rhizomes, especially compared to above-ground tissues (e.g., Ellis et al. 1994; Kumari and Tripathi 2015; Liu et al. 2007; Stark et al. 1988; Tanner 1996; Taylor and Crowder 1981; Ye et al. 2001a, b, c). For instance, Ellis et al. (1994) found $\mathrm{Cd}, \mathrm{Cu}, \mathrm{Pb}$, and $\mathrm{Zn}$ in T. latifolia from low exposure field sites was approximately two thirds in root and rhizome tissues and only one third in leaf tissues. In comparison, up to two orders of magnitude higher concentrations of $\mathrm{Cd}, \mathrm{Cu}, \mathrm{Fe}, \mathrm{Ni}, \mathrm{Pb}$, and $\mathrm{Zn}$ were found in roots and rhizomes compared to shoots of T. latifolia and P. australis in high exposure laboratory experiments (Batty and Younger 2003; Ye et al. 1997a, b). Furthermore, O'Sullivan et al. (2004) and Schierup and Larsen (1981) showed that metal (bio)availability for macrophytes is governed by geochemical and environmental factors, such as $\mathrm{pH}$, redox potential, speciation, carbon content, and temperature. Conversely, sediment $\mathrm{pH}$ and redox potential are in turn influenced by wetland plants, as reported for Typha populations by Sencindiver and Bhumbla (1988). Altogether, bioaccumulation is expected to prevail in shallow, bog-like wetlands and waterlogged anaerobic soils or sediments with low flow velocities allowing for adequate contact time between contaminated water and plant (roots) where metal uptake and fixation is correlated with soil-sediment concentration (Taylor and Crowder 1981). Nevertheless, most of the metals that are not precipitated in the water column are expected to be retained within the soil-sediment matrix, chiefly by sorption on plant detritus and sulphide precipitation in a reducing environment (e.g., Galletti et al. 2010; Karathanasis and Johnson 2003; Maine et al. 2006; Mays and Edwards 2001; O’Sullivan et al. 2004; Ye et al. 2001c). 
A more complex biogeochemical interaction is found in the rhizosphere where radial oxygen release from plant roots creates an aerobic-anaerobic interface of substantial areal extent (Armstrong et al. 1992; Dunbabin and Bowmer 1992). Iron and manganese plaque formation was observed for various plants and (metalliferous) environments directly on the root surface and throughout the sediment (Snowden and Wheeler 1995). It is still unclear whether this is simply a consequence of radial oxygen loss from roots or in fact a protective plant mechanism controlling metal phytotoxicity and uptake rates. In any case, it is clear that metal depositions act as a sink for not only iron, manganese, and aluminium (Batty and Younger 2003), but also several other trace contaminants associated with mining activities (As, $\mathrm{Cd}, \mathrm{Cu}, \mathrm{Pb}, \mathrm{Ni}$, and $\mathrm{Zn}$ ) as well as phosphate (e.g., Batty et al. 2000, 2002; Hansel et al. 2001; St-Cyr and Campbell 1996; Ye et al. 1997a, 2001a).

\section{Environmental Effects}

Dense macrophyte stands have considerable beneficial effects on constructed wetland functionality. Wetland macrophytes develop extensive rhizome and root systems throughout and above the substrate that physically stabilise the sediment, preventing resuspension of the accumulating ochre (James et al. 2004; Kadlec et al. 2000; Nyquist and Greger 2009). In addition, extensive and dense hydrophyte populations improve the microclimate through evapotranspiration and shading in summer as well as insulation and windbreak by senescent, erect macrophytes in winter (Brix
1994; García et al. 2003; Wittgren and Maehlum 1997). Water temperature in wetlands displays a more sluggish reaction and lower amplitude relative to settling ponds (Gearheart 1992). This effect is illustrated in Fig. 2 for the exemplifying pilot system, becoming slightly more pronounced in the second vegetation period due to increased maturity. In addition, fewer and less extreme water temperatures, particularly warm temperatures, were observed in the wetland compared to the settling pond, with maximum temperatures of 30.7 and $27.2^{\circ} \mathrm{C}$ measured in settling pond and wetland, respectively. More stable temperature conditions in wetlands prevent thermal currents or buoyancy effects and thus improve gravitational settling of particulate hydrous ferric oxides, although it may also lead to semi-permanent thermal stratifications that reduce the effective volume. Additionally, windbreaking by emergent stems and leaves contributes to the hydraulic efficiency of wetlands, especially compared to bare settling ponds, by reducing wave formation, water turbulence, dispersion, and most importantly, by preventing wind-driven currents transporting contaminated water from inflow to outflow with minimal retention time (Goodarzi et al. 2018; Thackston et al. 1987). Windbreaking also contributes to erosion control, preventing resuspension of settled flocs (Batty 2003; Braskerud 2001; Brix 1994).

\section{Hydraulic Effects}

Both settling ponds and wetlands basically provide retention time for natural biogeochemical reactions and
Fig. 2 Water temperature data from settling pond (orange lines) and wetland (green lines) of the pilot system described in Opitz et al. (2019) with a development over 2 years, b week detail from summer 2019 and $\mathbf{c}$ week detail from winter 2019 (all at 30-min measurement interval)
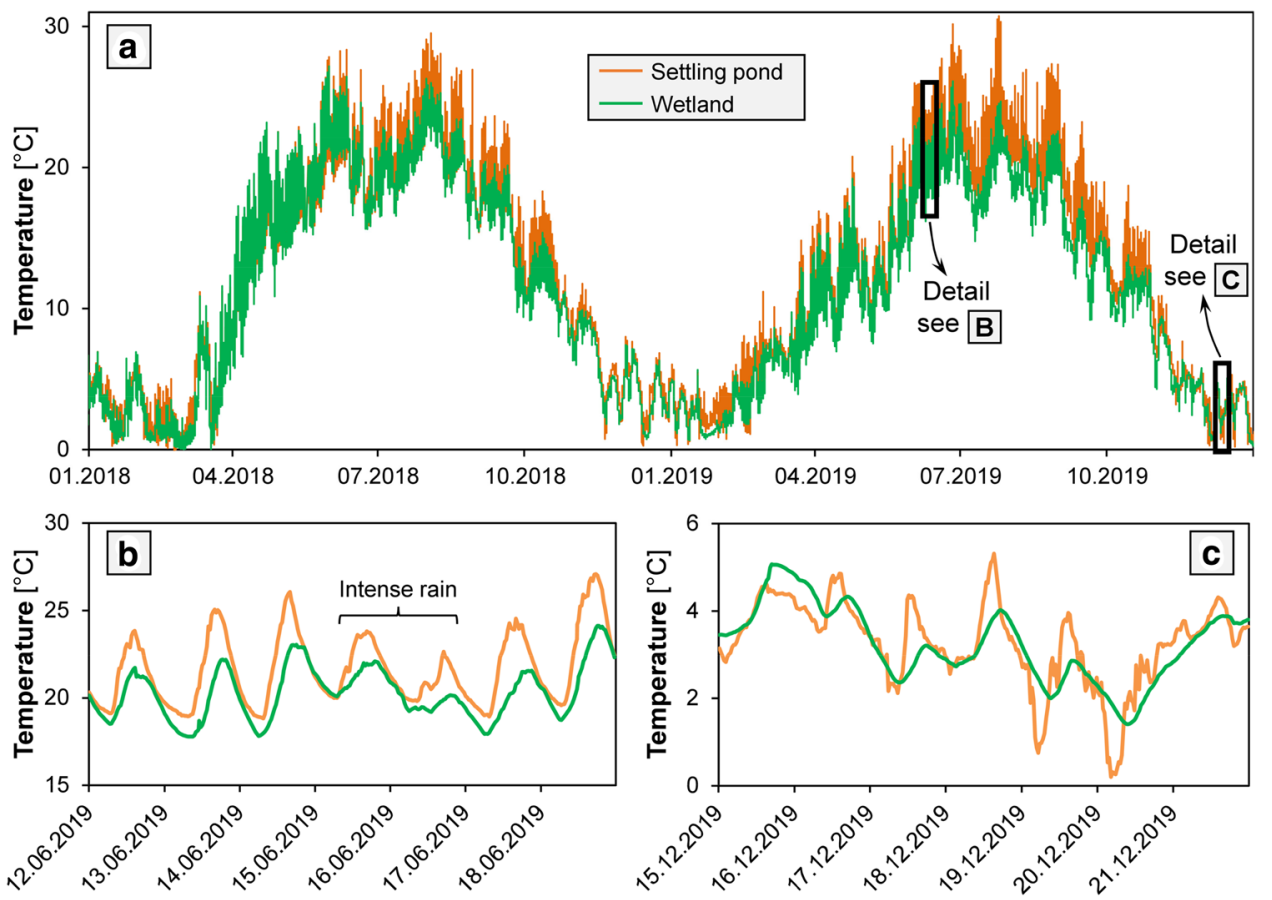
physical processes to proceed to completion (Jing et al. 2002). Besides accelerating or providing a better environment for respective reactions and processes as described above, macrophytes improve overall hydraulic efficiency and may ultimately increase the actual hydraulic retention time compared to bare settling ponds of equal size (Jadhav and Buchberger 1995; Persson et al. 1999). For example, Verschoren et al. (2017) conducted an experimental field comparison of a lowland river reach with fully developed, partially removed, and fully removed aquatic vegetation and reported that "vegetation free treatments [...] had the lowest hydraulic resistance, the highest flow velocity, the highest longitudinal dispersion coefficient, the largest transient storage zone, and the lowest retention of particulate matter." Improved hydraulics in wetlands compared to unvegetated ponds are attributable to several effects that are directly related to macrophyte vegetation as natural hydraulic obstacles (e.g., Braskerud 2001; Buchberger and Shaw 1995; Horvath 2004; Jadhav and Buchberger 1995; Kadlec 1994; Laurent et al. 2015; Nepf 1999; Persson et al. 1999; Su et al. 2009), including but not limited to:

- Increased mixing, flow distribution and flow regulation encouraging more homogeneous hydrodynamics (approaching "plug flow");

- Reduced flow velocities and more regular velocity profiles in the vertical direction;

- Less dead or stagnant zones, stratification, dispersion, and preferential or open-channel flow ("short-circuiting");

- Reduced wind-related effects (see above).

For details on quantitative aspects such as hydraulic efficiency in general and effects of wetland vegetation in particular, the reader is kindly referred to respective specialised literature (e.g., Kadlec 1994; Persson et al. 1999; Thackston et al. 1987). Altogether, hydraulic retention time and advective transport increase with greater vegetation density (Braskerud 2001; Jadhav and Buchberger 1995). It is important to note that the effect of vegetation on hydraulic efficiency strongly depends on flow regime, vegetation type and density, as well as pond shape, length:width ratio, and layout (Guo et al. 2017; Persson et al. 1999; Persson and Wittgren 2003; Su et al. 2009). Badly maintained wetlands with spatially irregular vegetation distribution or silting up can have opposite effects, such as flow channelling or plugging (Brix 1994; Jadhav and Buchberger 1995; Klerk et al. 2016; Persson et al. 1999; Wahl et al. 2012). Field tracer tests of various settling ponds and wetlands in UK passive mine water treatment systems showed better hydraulic efficiency for wetlands, whereas the effective volume of settling ponds was often considerably reduced due to dispersed flow, poor mixing, and short-circuiting (Kruse et al. 2009; Kusin et al. 2010; Sapsford 2013).

\section{Ancillary and Secondary Benefits}

Besides contributing to water quality improvement and system operation, the supplemental benefits of wetland vegetation should not be underestimated (Batty and Younger 2002). First and foremost, the near-natural appearance of lush, green wetlands increases the aesthetic appearance of the treatment system, especially compared to bare settling ponds or conventional reactor-based (chemical) treatment plants (Batty 2003). The value of wetland ecosystems beyond the intrinsic treatment purpose nowadays represented and evaluated by various ecosystem services is, without going into further detail, often widely underestimated (e.g., Liquete et al. 2016; Masi et al. 2018; McInnes 2013; Mitsch et al. 2014). In addition, constructed wetlands provide wildlife shelter and habitat with diverse biotopes and ecological or structural niches for various (even protected) aquatic and semi-aquatic species (Knight 1997; Knight et al. 2001; Lacki et al. 1992). Although constructed wetlands may develop a spatially inclusive and comprehensive, yet structurally diverse mosaic of predominantly reed beds or sedge reeds, most mine water treatment wetlands display less overall floral (and faunal) diversity compared to natural wetlands due to the monocultural reed or cattail structure (Knight 1997). This is mostly due to the technical design and management of treatment wetlands, where the primary consideration is preservation of hydraulic and treatment performance (Thullen et al. 2005). Nevertheless, constructed wetlands contribute to the restoration, development, and conservation of functioning ecological interrelations, biodiversity, wildlife corridors, and biotope networks in post-mining landscapes (Batty 2005; Feierabend 1989; Klerk et al. 2016; Yang et al. 2006). Biological water quality, which is increasingly introduced as a monitoring and valuation parameter (e.g., EU Water Framework Directive biological quality elements, U.S. EPA Biological Water Quality Criteria Program), is considerably improved through development of the increasingly diverse aquatic micro- and macro fauna within passive systems, and thus before discharge to freshwater environments. Secondary benefits such as these may become increasingly important to the acceptance level of passive mine water treatment plants amongst stakeholders, particularly residents, and environmental authorities.

Macrophyte metabolism (especially uptake and assimilation) as well as stimulation of biological activity and selfsustaining nutrient or substance cycles in wetlands lead to biotransformation of organic compounds potentially present in mine waters, such as carbon- or nitrogen-based residues from explosives or cyanidation (Koren et al. 2000; Zaitsev 
et al. 2008) as well as carbon fixation (Mitsch et al. 2012). Elevated ammonia in coal mining discharges originating from degradation of organic residues in coal or lignite deposits is reduced through plant uptake and assimilation as well as autoxidative transformation towards nitrate in oxygenated wetland environments (Vymazal 2013). It is, however, important to note that the aquatic nitrogen cycle is predominantly limited to nitrification in the prevailing oxygenated environment in mine water treatment wetlands (Demim and Dudeney 2003). In any case, wetland macrophytes show high organic pollutant assimilation and removal capacities that may additionally improve mine water quality (Tanner 1996). Synergetic cotreatment of mine- and wastewater in constructed wetlands is also increasingly tested worldwide (Makhathini et al. 2020).

In summary, noteworthy (ecological) effects, amenity value, ecosystem services, and secondary benefits of wetland macrophytes, although not directly contributing to metal removal, are of considerable and increasing importance to stakeholder management, approval procedures, and environmental impact assessments. Respective environmental and ecological aspects as well as landscape diversity should not be underestimated, particularly in post-mining landscapes. Environmental benefits and ecological value are expected to increase with long-term operation and concomitant wetland maturation (Kadlec et al. 2000; Stark et al. 1988). Therefore, ecological development of constructed wetlands should be given due consideration during the technical planning stage and approval procedure.

\section{Drawbacks and Limitations}

\section{Biochemical Problems}

From a biogeochemical perspective, continuous decomposition of plant litter in wetlands increases dissolved and particulate organic carbon in the water (Noller et al. 2003). Ensuing metabolic, photolytic, or autoxidative decomposition result in oxygen consumption throughout the water column. In extreme cases, this may lead to oxygen depletion, not only along the flow path, but also towards the sediment surface, and even reducing conditions within the substrate or directly above the sediment-water interface. Especially at low flow velocities or (temporally) stagnant conditions, intensive NOM generation and concomitant decomposition can substantially decrease both dissolved oxygen and redox potential (Kirby et al. 1999; Pedescoll et al. 2015). This is not to be underestimated, particularly during the growing season, as illustrated in Fig. 4 for the exemplifying pilot system where, in contrast to the settling pond, oxygen saturation in the wetland dropped below $50 \%$ in summer when NOM generation was highest and oxygen solubility lowest.
This may lead to retarded ferrous iron oxidation in the water and even ferric iron reduction in the sediment, the latter temporarily remobilising iron. This spatially and temporally increase in iron redox cycle complexity may potentially affect overall treatment performance (Johnson and Hallberg 2002), although no corresponding observations of significantly compromised treatment performance are reported.

\section{Seasonal Variability}

It is important to note that most macrophyte-related effects are subject to considerable variability, mostly due to seasonal, hydraulic, and stochastic fluctuations in wetland environments (Johnson and Hallberg 2002; Kadlec et al. 2000). First and foremost, plants directly participate in material cycles in their immediate environment through photorespiration, i.e., photosynthesis during the day and cellular respiration during the night, with the overall $\mathrm{O}_{2}-\mathrm{CO}_{2}$ budget benefitting oxygen production. Unlike terrestrial plants, hydrophytes not only affect gas equilibria in the atmosphere but also in the surrounding aqueous environment. Mine discharges are often suboxic and oversaturated with $\mathrm{CO}_{2}$, the latter lowering the $\mathrm{pH}$ of the water. This directly and substantially affects metal oxidation reaction kinetics, with oxidation rates declining with a decrease in dissolved oxygen and/or pH (Geroni et al. 2012). During the day, wetland macrophytes vertically transport oxygen through the aerenchyma to the roots and thus into the water column and sediment (Armstrong et al. 1992; Brix et al. 1992). Concomitantly, dissolved $\mathrm{CO}_{2}$ or bicarbonate diffuse into the plant, promoting photosynthesis:

$$
\begin{aligned}
& 6 \mathrm{CO}_{2}+12 \mathrm{H}_{2} \mathrm{O} \rightarrow \mathrm{C}_{6} \mathrm{H}_{12} \mathrm{O}_{6}+6 \mathrm{O}_{2}+6 \mathrm{H}_{2} \mathrm{O} \\
& 6 \mathrm{HCO}_{3}^{-}+6 \mathrm{H}_{2} \mathrm{O} \rightarrow \mathrm{C}_{6} \mathrm{H}_{12} \mathrm{O}_{6}+6 \mathrm{OH}^{-}+6 \mathrm{O}_{2}
\end{aligned}
$$

This uptake of dissolved inorganic carbon accelerates $\mathrm{CO}_{2}$-stripping in respectively oversaturated mine waters and thus increases or stabilises the $\mathrm{pH}$, which in turn is one of the determining factors in most biogeochemical redox cycles. In the circumneutral range, an increase by up to one pH-unit thorough $\mathrm{CO}_{2}$-stripping was reported by Geroni et al. (2012) and Opitz et al. (2019), which may increase iron oxidation 100-fold (Dempsey et al. 2001). However, while the $\mathrm{pH}$ increase would have a positive impact on ferrous iron oxidation, wetlands may display considerable $\mathrm{pH}$ fluctuation in either direction due to uptake of dissolved inorganic carbon by algae and macrophytes as well as the release of organic acids, as illustrated for the exemplifying pilot system in Fig. 3. Overall, biological processes in the wetland resulted in a lower median $\mathrm{pH}$ (about 0.5 units) compared to the preceding settling pond that only featured 
Fig. $3 \mathrm{pH}$ data from settling pond (orange lines) and wetland (green lines) of the pilot system described in Opitz et al. (2019) with a development over 1 year, b week detail from April 2019 and $\mathbf{c}$ distribution curve of the year-round $\mathrm{pH}$-dataset (all at 30-min measurement interval)
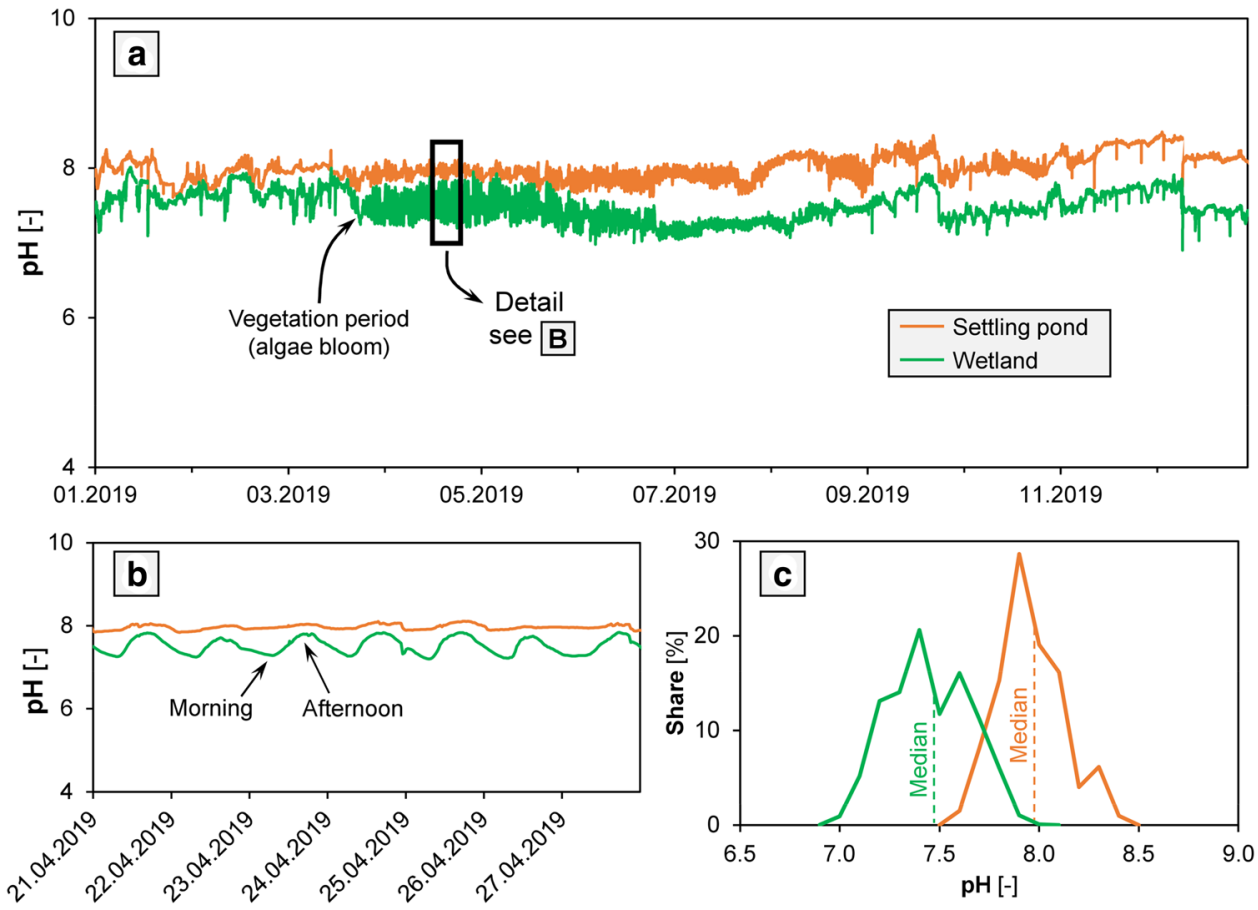

Fig. 4 Dissolved oxygen data from settling pond (orange lines) and wetland (green lines) of the pilot system described in Opitz et al. (2019) with a development over 2 years, b week detail from April 2019 and c distribution curve of the yearround oxygen concentration dataset (all at 30-min measurement interval)
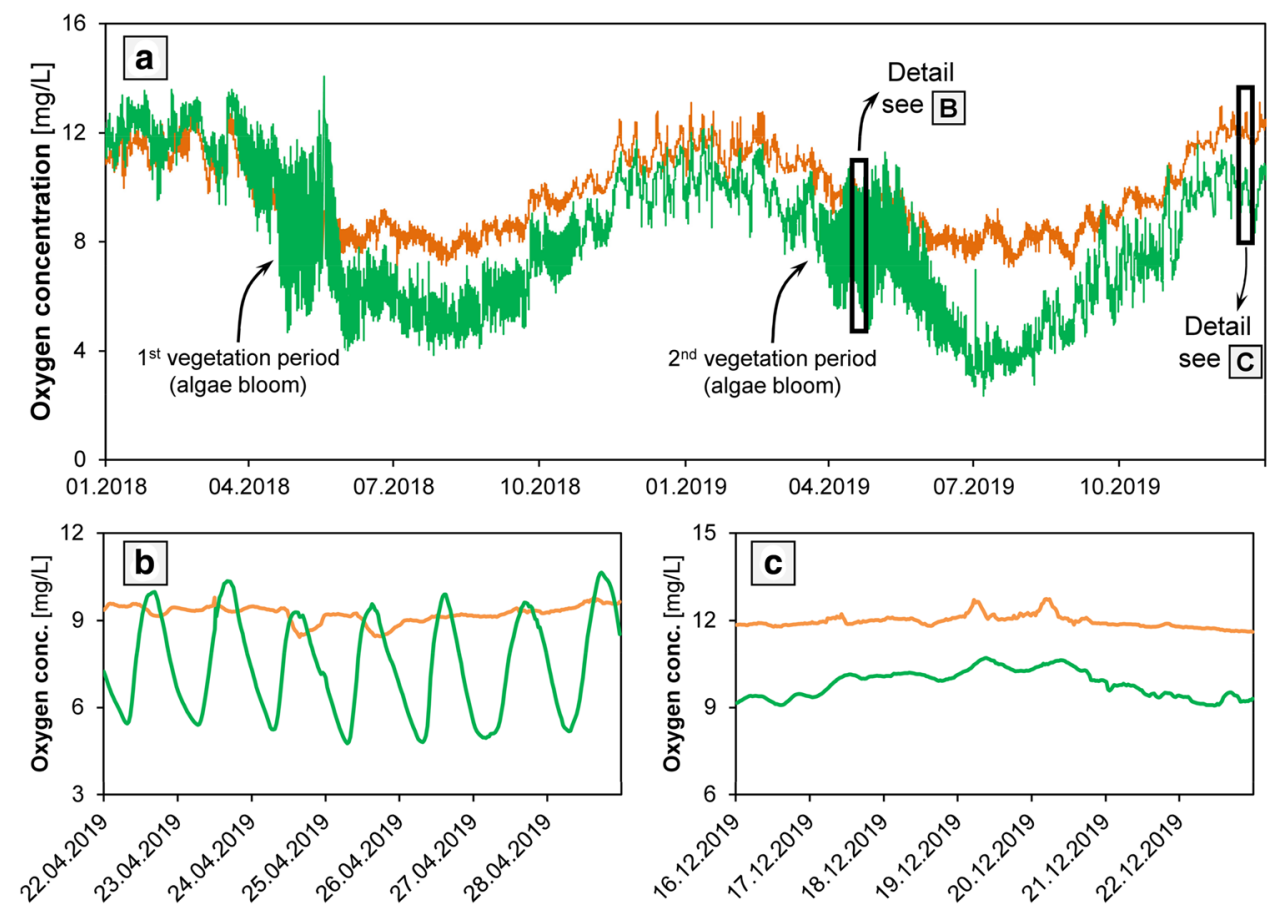

natural $\mathrm{CO}_{2}$-degassing, especially during spring and summer (Fig. 3c).

Common wetland macrophytes can transfer to and radially release up to several hundred $\mathrm{mg} / \mathrm{m}^{2} / \mathrm{h}$ of oxygen from the rhizomes (Brix and Schierup 1990; Watson et al. 1989). Reversal of the process during the night results in diurnal oxygen cycles with maxima early in the afternoon and minima during the night, further amplified by microbial oxygen consumption upon NOM decomposition and temperaturedependence of oxygen solubility (Dempsey et al. 2001). Since only the latter is relevant in settling ponds, the dissolved oxygen amplitude is, again, considerably larger in 
wetlands compared to settling ponds as illustrated for the exemplifying pilot system in Fig. 4a. Diurnal fluctuation of dissolved oxygen in wetlands is exceptionally pronounced during algae blooms with amplitudes easily between 50 and $110 \%$ saturation (Fig. 4b) and still noticeable after full emergence of herbaceous macrophytes, yet negligible in winter (Fig. 4c). In contrast, settling ponds are expected to display relatively stable and high oxygen saturation throughout the year unless oxygen is consumed by ferrous iron oxidation. Altogether, increased oxygen solubility with decreasing temperature results in lower oxygen concentrations in summer and in the night and higher oxygen concentrations in winter at daytime for both settling ponds and wetlands, yet this is considerably pronounced in wetlands during the vegetation period (Gu et al. 2006). With homogeneous ferrous iron oxidation showing first-order dependency on oxygen concentration and inversely second-order dependency on proton activity, a shift in dissolved oxygen and/or pH inevitably affects oxidation rates and thus treatment efficiency (Dempsey et al. 2001; Hustwit et al. 1992).

Total suspended solids (TSS) content in wetland outflows can also display considerable seasonal patterns, with increased effluent TSS during the growing season due to generation of particulate NOM by vegetation growth and decay (Kadlec et al. 2000). Regarding mine water treatment wetlands, it is important to note that increased effluent TSS in summer predominantly concerns wetland-derived particulate matter (i.e., the "natural background"; Gearheart 1992), whereas effluent suspended hydrous ferric oxides are expected to decrease with vegetation development (filtration) and NOM generation during the growing season (scavenging) and increase with vegetation dieback in winter (Opitz et al. 2020). Moreover, Braskerud (2001) found that the effect of wetland vegetation on hydraulic efficiency was linked to seasonal vegetation development, increasing during the summer und decreasing during winter, with hydraulic efficiencies of 0.86 and 0.78 , respectively.

Altogether, ecological and thus macrophyte-related fluctuations in hydrochemical parameters such as $\mathrm{pH}$, dissolved oxygen, and TSS, as well as temperature (see Fig. 2) have both positive and negative effects on metal removal mechanisms and kinetics. Therefore, wetland performance evaluation is usually recommended on an averaged time span basis (several seasons or years) rather than on individual measured values to accommodate natural fluctuations in open systems (Kadlec et al. 2000). In contrast to surface-flow wastewater treatment wetlands, mine water treatment wetlands usually display less performance fluctuation due to ecological or seasonal variability, with physico-chemical iron and TSS removal only moderately affected by environmental variations (Gu et al. 2006; Hedin 2008). Rather, treatment efficiency is more often affected by stochastic fluctuations as well as distinct variations in consequence of inconsistent hydraulic loading or retention time (Opitz et al. 2020; Stark et al. 1994). The effect of environmental and especially gas transfer effects on passive system performance may be reduced by ensuring thorough aeration at the inlet of (and potentially between) ponds (Cravotta 2007, 2015; Geroni et al. 2012).

\section{Technical Difficulties}

With treatment efficiency governed by wetland macrophytes, there are nevertheless drawbacks of near-natural wetlands compared to settling ponds. Although wetlands are considered a low-cost and low-maintenance technology, regular service is required to maintain ecological as well as biogeochemical and hydraulic integrity (Hedin 2020). First and foremost, wetlands require maintenance to prevent deterioration of hydraulic performance as the carefully engineered conditions that facilitate initial macrophyte establishment degrade over time. The most frequent problems include plugging, silting up, and hydrosere due to accumulating plant litter, detritus, and ochre. Receding plant cover may lead to laterally fringing vegetation with increased flow velocity through the unvegetated middle ("short-circuiting"; Jenkins and Greenway 2005; Persson et al. 1999). Detrimental conditions or pest infestation may lead to deterioration of vegetation structure and habitat value or altogether perishing of (monocultural) vegetation, warranting accompanying landscape preservation measures (Brodie 1991; Snoddy et al. 1989; Thullen et al. 2005).

It was also noted at several sites that newly constructed wetlands require up to three vegetation cycles for full maturation, which was mostly attributed to progressive development and coverage of plant communities (Fennessy and Mitsch 1989; Stark et al. 1988; Wildemann et al. 1993), but likely also applies to bacterial communities (Samsó and García 2013). If regulatory standards must be met from day one, it may prove necessary to either oversize the system, as recommended by Wildemann et al. (1993) or to (transitionally) install an additional sediment filter for effluent polishing, as successfully demonstrated by Opitz et al. (2019, 2020).

\section{Waste Disposal}

In surface-flow wetlands, a substrate depth of about $0.3 \mathrm{~m}$ is usually sufficient for macrophyte roots to find stable grounding, although the root zone may naturally extend much deeper, and to support hydrophytic plant life (Kadlec and Wallace 2009; Laine and Jarvis 2003). Accretion of metal (hydr)oxides and plant litter on top of the rooting soil results in an accruing sediment. Most organic residues (e.g., cellulose, hemicellulose) are readily biodegradable and thus decomposed and overturned rapidly, especially during 
elevated summer temperatures (Álvarez and Bécares 2006; Chimney and Pietro 2006). However, Álvarez and Bécares (2006) estimated that only approximately two thirds of $T$. latifolia detritus decomposes within the first year, with persistent structural polymers such as lignin remaining. Consequently, sediment accumulation in wetlands is faster and characterised by a more heterogeneous composition than settling ponds. In the long run, this may ultimately result in sediment build-up and hydrosere, necessitating excavation and refurbishment of the constructed wetland.

Generally, settling ponds are designed to retain the bulk of ochre solids and thus require more frequent sludge removal than wetlands (Nuttal 2003). The accumulating sediment in settling ponds predominantly consists of hydrous ferric oxides, with some allochthonous (e.g., biotic or wind-borne) material (Fig. 5a). The ochreous sludge is easily removed and dewatered (Dempsey and Jeon 2001), and either disposed of or used for various purposes, subject to composition (e.g., Hedin 2003; Sapsford et al. 2015). Polishing wetlands exhibit longer life spans, despite the additional accumulation of organic matter. Wetland sediments consist of the original soil substrate, accumulated hydrous ferric oxides, and a substantial amount of organic matter comprising litter, roots, and detritus in various stages of decomposition (Fig. 5b) (Kadlec et al. 2000). The heterogeneous material is usually unfit for valorisation, and the organic content complicates or altogether prevents landfill disposal. There is a longstanding discussion regarding appropriate utilisation as opposed to disposal of ochreous and organic-rich substrates excavated from mine water treatment wetlands that is ultimately governed by the applicable legal framework. Even if contamination of the mine water and thus the sediment is basically limited to $\mathrm{Fe}, \mathrm{Al}$, and $\mathrm{Mn}$, the material may still be technically classified as waste material and thus require complex screening and permission procedures as well as pre-treatment (i.e., oxidation and stabilisation) for reuse in

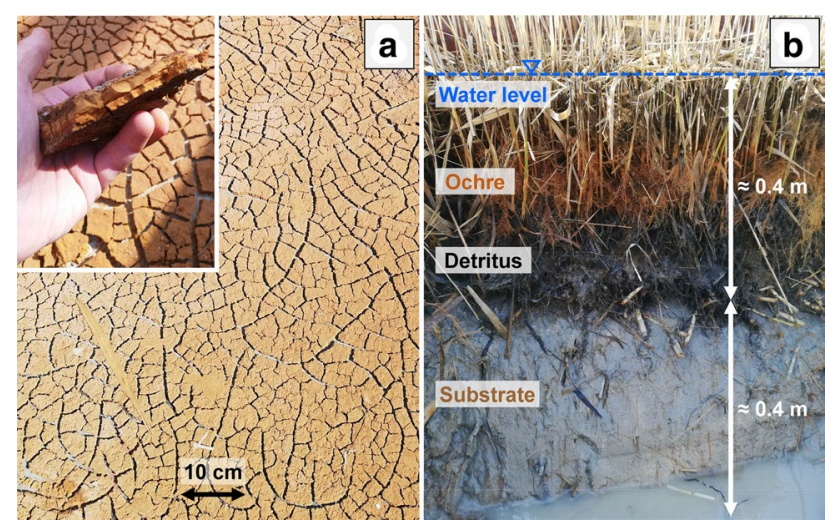

Fig. 5 Photos of $\mathbf{a}$ sun-dried ochre in a settling pond and $\mathbf{b}$ profile of a drained surface-flow reed wetland from the pilot system described in Opitz et al. (2019) the environment as, for instance, soil amendment or topsoil. Furthermore, wetlands may require a little more routine effort for maintenance of optimal hydraulic, ecological, and technical conditions (e.g., prevention of clogging or silting up, pest prevention) and refurbishment, the latter requiring the removal of rhizomes prior to sludge removal for reuse after replenishing of the substrate layer.

\section{Discussion}

Designing and planning of passive systems, particularly at legacy or socialised mine sites, is often inevitably guided by economic considerations and land area availability. Obviously, iron removal in unvegetated settling ponds is mostly limited to chemical oxidation of dissolved ferrous iron and physical sedimentation of settleable hydrous ferric oxides, whereas colloidal hydrous ferric oxides often break through settling ponds due to their low settling velocities. In contrast, this review clearly shows that vegetated surface-flow wetlands are in many ways more effective for iron removal due to a variety of auxiliary processes and effects. Most importantly, macrophyte-related filtration, in combination with physico-chemical, biogeochemical, and hydraulic effects, are indispensable for not only removal of settleable hydrous ferric oxides, but also polishing of residual dissolved ferrous iron and ferric colloids where mere gravitational sedimentation would require several days. The effective removal of residual iron is of major importance to reliably meet (strict) regulatory standards.

However, it is important to note that the macrophyte-related advantage in treatment performance goes hand in hand with additional effort and expenditure in operation, maintenance, cleanout, and restoration (Kadlec et al. 2000). Accordingly, overloading of wetlands will rapidly smother and clog macrophyte stands, resulting in declining treatment efficiency and shorter restoration cycles. This trade-off led to the current state of the art, where settling ponds and wetlands are serially connected in composite passive systems for pre-treatment of the bulk iron loading and polishing of residual iron, respectively, as outlined in Table 1 (Hedin et al. 1994). This way, both overall system performance and efficiency are increased, whilst protecting wetlands from overloading.

Unfortunately, quantitative target criteria recommendations, especially for pre-treatment, are limited to rather rough approximations, for instance aiming at 50-70\% iron removal in upstream settling ponds (Dey et al. 2003; Parker 2003). A 50\% reduction of a highly ferruginous inflow may, however, still result in wetland overloading, especially if the wetland receives high concentrations of ferrous iron. Similar problems may be observed for the long-established area-adjusted iron removal concept for neutral or alkaline mine water outlined by Hedin et al. 
Table 1 Juxtaposition of core advantages and disadvantages of settling ponds and wetlands for iron removal

\begin{tabular}{lll}
\hline Iron removal process & Settling ponds & Wetlands \\
\hline Ferrous iron oxidation & + Good oxygen transfer & + Catalytic plant surfaces \\
& + Ample residence time & + Growth surfaces for bacteria \\
& + Plentiful dispersed catalytic surfaces & + Hydraulic efficiency \\
& + Warm summer temperatures & + Vertical oxygen transport by plants \\
& + Mixing and turbulence (wind, buoyancy, etc.) & - Decompositional oxygen depletion \\
& + Effective $\mathrm{CO}_{2}$ degassing & - pH amplitude \\
& - Poor hydraulic efficiency & - Little mixing \\
& - Cold winter temperatures & - Diurnal and seasonal variability \\
& + Gravitational settling & + Gravitational settling \\
Removal of hydrous ferric oxides & + Intensive (homo)aggregation & +Filtration by dense vegetation \\
& + Large sludge storage capacity & + Heteroaggregation \\
& + Ample residence time & +Scavenging by organic matter \\
& - Mixing and turbulence & + Quiescent body of water \\
& - Potential re-suspension & + Hydraulic efficiency \\
Primary field of application & - Poor hydraulic efficiency & - Small sludge storage capacity \\
& Broad ferrous iron oxidation and aggregation-based sedi- & Effective removal of both dissolved \\
& mentation of the bulk loading & and suspended residual iron \\
\hline
\end{tabular}

(1994). Both percentage- and area-adjusted removal concepts are, according to the principles of mass action, concentration-independent (i.e., linear) approaches and thus tend to under- and overestimate iron removal at high and low iron loadings, respectively (Hedin et al. 1994; Hedin 2008). Thus, current engineering guidelines fail to provide an adequate quantitative basis for customised design and sizing of settling ponds for pre-treatment and wetlands for polishing (Sapsford and Watson 2011). To optimally exploit the respective advantages of both treatment units and thus minimise the areal footprint and overhead of composite passive systems, it will be necessary to develop a better quantitative understanding of the concentrationdependent relationships between pond size (or hydraulic retention time) and iron removal kinetics.

\section{Summary}

Positive effects of macrophytes on passive mine water treatment are mostly attributable to a variety of (interrelated) processes and factors conglomerated in the wetland-specific aquatic and benthic environment (Fig. 6). The main conclusion of this review is that the contribution of macrophytes to water quality in general and iron/metal removal from mine drainage in particular becomes especially important for low or residual iron concentrations due to a number of mechanisms and effects that are intrinsic to wetland environments and do not occur in bare settling ponds:

- Enhanced biogeochemical oxidation and precipitation of hydrolysable metals due to catalytic reactions and bacterial activity on immersed macrophyte surfaces;
- Physical filtration of colloidal hydrous ferric oxides that are unlikely to gravitationally settle within a given retention time by dense wetland vegetation;

- Scavenging and heteroaggregation of dissolved and colloidal iron, respectively, by plant-derived NOM;

- Improved hydrodynamics and hydraulic efficiency of vegetated treatment ponds, considerably augmenting retention and exposure time.

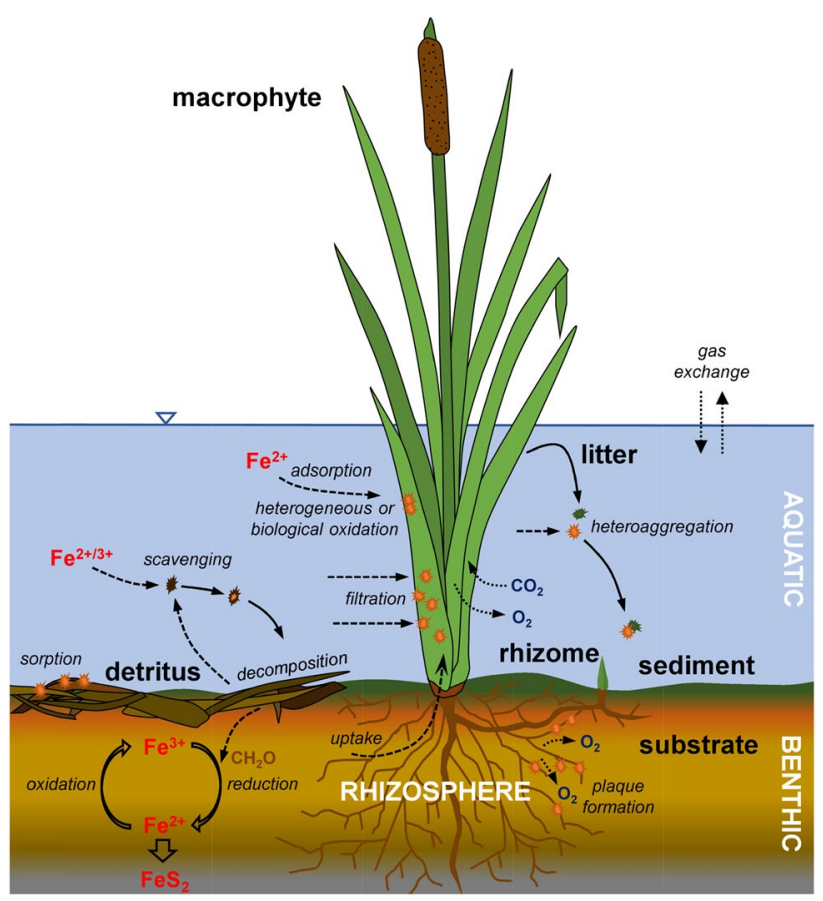

Fig. 6 Schematised effects of macrophytes on iron (metal) removal in surface-flow wetlands 
While this review provides an extensive qualitative overview of macrophyte-related effects on passive mine water treatment, we emphasise that quantification of, for a start, the individual effects described above, but principally the overall contribution of macrophytes specifically to metal/iron removal is limited to complex, predominantly site-specific, and thus untransferable model approaches. One of the main reasons is the unknown number and magnitude as well as the variability of vegetation-related influencing factors (Brisson and Chazarenc 2009; Kuehn and Moore 1995). Comparative studies of settling ponds and especially wetlands showed that performance may be similar under comparable conditions yet may vary considerably due to primary influencing factors, such as contaminant loading or retention time, and potential secondary (i.e., ecological) factors such as plant species, density, and development as well as seasonal patterns, and water and substrate depth. Although the literature provides various approaches to estimate macrophyte effects on the removal of particulate matter (especially clastic sediments and other natural particles) in wetlands and small lotic systems, little of this data is easily transferable to other cases, much less usable or applicable for actually designing or sizing constructed mine water treatment wetlands. Nevertheless, as both Pluntke and Kozerski (2003) and Saiers et al. (2003) found the suspended concentration of micrometre particles and submicron colloids, respectively, to be the most likely determining factor for macrophyte-related particle retention under similar hydrodynamic conditions, we speculate that a way forward may be the systematic empirical or model-based determination of simplified iron removal relationships or rates. At the very least, a roughly estimated "filtration-factor" for wetlands compared with or relative to settling ponds would help to more specifically deploy either component in composite passive systems.

Well-designed and -maintained, fully mature constructed wetlands continually and reliably achieve iron removal rates $>90 \%$, little short of conventional, chemical treatment plants. Nevertheless, this study shows that the choice between and optimal sizing of settling ponds and wetlands in a composite passive system must consider the intrinsic advantages and limitations of the two components. Optimal system design requires an elaborate concept that duly considers economic, ecologic, and legal aspects. A much better knowledge of iron/metal removal kinetics in surface-flow mine water treatment systems would facilitate optimised apportionment and consequential specific sizing of the two treatment stages, for instance settling ponds and wetlands deliberately designed to first lower iron concentration to $\approx 5-10 \mathrm{mg} / \mathrm{L}$ and then below the site-specific legal limit (polishing).
Acknowledgements The study was conducted as part of a research project funded by the German Federal Environmental Foundation (project 33012/01-23).

Funding Open Access funding enabled and organized by Projekt DEAL.

Open Access This article is licensed under a Creative Commons Attribution 4.0 International License, which permits use, sharing, adaptation, distribution and reproduction in any medium or format, as long as you give appropriate credit to the original author(s) and the source, provide a link to the Creative Commons licence, and indicate if changes were made. The images or other third party material in this article are included in the article's Creative Commons licence, unless indicated otherwise in a credit line to the material. If material is not included in the article's Creative Commons licence and your intended use is not permitted by statutory regulation or exceeds the permitted use, you will need to obtain permission directly from the copyright holder. To view a copy of this licence, visit http://creativecommons.org/licenses/by/4.0/.

\section{References}

Álvarez JA, Bécares E (2006) Seasonal decomposition of Typha latifolia in a free-water surface constructed wetland. Ecol Eng 28(2):99-105. https://doi.org/10.1016/j.ecoleng.2006.05.001

Armstrong J, Armstrong W, Beckett PM (1992) Phragmites australis: Venturi- and humidity-induced pressure flows enhance rhizome aeration and rhizosphere oxidation. New Phytol 120(2):197-207. https://doi.org/10.1111/j.1469-8137.1992.tb05655.x

Banfield JF, Welch SA, Zhang H, Ebert TT, Penn RL (2000) Aggregation-based crystal growth and microstructure development in natural iron oxyhydroxide biomineralization products. Science 289(5480):751-754. https://doi.org/10.1126/science.289.5480. 751

Batty LC (2003) Wetland plants - more than just a pretty face? Land Contam Reclamat 11(2):173-180. https://doi.org/10.2462/09670 513.812

Batty LC (2005) Wetland systems associated with mine sites as a source of biodiversity. In: Loredo J, Pendás F (eds), Proc, 9th IMWA Congress, Oviedo, pp 525-531

Batty LC, Younger PL (2002) Critical role of macrophytes in achieving low iron concentrations in mine water treatment wetlands. Environ Sci Technol 36(18):3997-4002. https://doi.org/10.1021/ es020033+

Batty LC, Younger PL (2003) Effects of external iron concentration upon seedling growth and uptake of $\mathrm{Fe}$ and phosphate by the common reed, Phragmites australis (Cav.) Trin ex. Steudel. Ann Bot 92(6):801-806. https://doi.org/10.1093/aob/mcg205

Batty LC, Younger PL (2004) Growth of Phragmites australis (Cav.) Trin ex. Steudel in mine water treatment wetlands: effects of metal and nutrient uptake. Environ Pollut 132(1):85-93. https:// doi.org/10.1016/j.envpol.2004.03.022

Batty LC, Baker AJ, Wheeler BD, Curtis CD (2000) The Effect of pH and plaque on the uptake of $\mathrm{Cu}$ and $\mathrm{Mn}$ in Phragmites australis (Cav.) Trin ex. Steudel. Ann Bot 86(3):647-653. https://doi.org/ 10.1006/anbo.2000.1191

Batty LC, Hooley D, Younger PL (2008) Iron and manganese removal in wetland treatment systems: rates, processes and implications for management. Sci Total Environ 394(1):1-8. https://doi.org/ 10.1016/j.scitotenv.2008.01.002

Bavor HJ, Davies CM, Sakadevan K (2001) Stormwater treatment: do constructed wetlands yield improved pollutant management 
performance over a detention pond system? Water Sci Technol 44(11-12):565-570. https://doi.org/10.2166/wst.2001.0881

Bezbaruah AN, Zhang TC (2004) pH, Redox, and oxygen microprofiles in rhizosphere of bulrush (Scirpus validus) in a constructed wetland treating municipal wastewater. Biotechnol Bioeng 88(1):6070. https://doi.org/10.1002/bit.20208

Braskerud BC (2001) The influence of vegetation on sedimentation and resuspension of soil particles in small constructed wetlands. J Environ Qual 30(4):1447-1457. https://doi.org/10.2134/jeq20 $01.3041447 \mathrm{X}$

Brenner EK, Brenner FJ, Brovard S, Schwartz TE (1993) Analysis of wetland treatment systems for acid mine drainage. J Penn Acad Sci 67(2):85-93

Brisson J, Chazarenc F (2009) Maximizing pollutant removal in constructed wetlands: Should we pay more attention to macrophyte species selection? Sci Total Environ 407(13):3923-3930. https:// doi.org/10.1016/j.scitotenv.2008.05.047

Brix H (1994) Functions of macrophytes in constructed wetlands. Water Sci Technol 29(4):71-78. https://doi.org/10.2166/wst. 1994.0160

Brix H, Schierup HH (1990) Soil oxygenation in constructed reed beds: the role of macrophyte and soil-atmosphere interface oxygen transport. Proc, International Conf on the Use of Constructed Wetlands in Water Pollution Control, Cambridge, pp 53-66

Brix H, Sorrell BK, Orr PT (1992) Internal pressurization and convective gas flow in some emergent freshwater macrophytes. Limnol Oceanogr 37(7):1420-1433. https://doi.org/10.4319/lo.1992. 37.7.1420

Brodie GA (1991) Achieving compliance with staged, aerobic, constructed wetlands to acid drainage. Proc, 1991 National ASMR Meeting, Durango, pp 151-174. https://doi.org/10.21000/JASMR 91010151

Buchberger SG, Shaw GB (1995) An approach toward rational design of constructed wetlands for wastewater treatment. Ecol Eng 4(4):249-275. https://doi.org/10.1016/0925-8574(94)00053-8

Chabbi A (1999) Juncus bulbosus as a pioneer species in acidic lignite mining lakes: interactions, mechanism and survival strategies. New Phytol 144(1):133-142. https://doi.org/10.1046/j.14698137.1999.00503.X

Chimney MJ, Pietro KC (2006) Decomposition of macrophyte litter in a subtropical constructed wetland in south Florida (USA). Ecol Eng 27(4):301-321. https://doi.org/10.1016/j.ecoleng.2006.05. 016

Cotton JA, Wharton G, Bass JA, Heppell CM, Wotton RS (2006) The effects of seasonal changes to in-stream vegetation cover on patterns of flow and accumulation of sediment. Geomorphology 77(3-4):320-334. https://doi.org/10.1016/j.geomorph.2006.01. 010

Cravotta CA (2007) Passive aerobic treatment of net-alkaline, ironladen drainage from a flooded underground anthracite mine, Pennsylvania, USA. Mine Water Environ 26(3):128-149. https:// doi.org/10.1007/s10230-007-0002-8

Cravotta CA (2015) Monitoring, field experiments, and geochemical modeling of $\mathrm{Fe}$ (II) oxidation kinetics in a stream dominated by net-alkaline coal-mine drainage, Pennsylvania, USA. Appl Geochem 62:96-107. https://doi.org/10.1016/j.apgeochem.2015.02. 009

de Klerk AR, Oberholster PJ, van Wyk JH, Truter JC, Schaefer LM, Botha AM (2016) The effect of rehabilitation measures on ecological infrastructure in response to acid mine drainage from coal mining. Ecol Eng 95(1):463-474. https://doi.org/10.1016/j.ecole ng.2016.06.070

Demim OA, Dudeney AWL (2003) Nitrification in constructed wetlands treating ochreous mine water. Mine Water Environ 22(1):15-21. https://doi.org/10.1007/s102300300003
Dempsey BA, Jeon BH (2001) Characteristics of sludge produced from passive treatment of mine drainage. Geochem Explor Env Anal 1(1):89-94. https://doi.org/10.1144/geochem.1.1.89

Dempsey BA, Roscoe HC, Ames R, Hedin RS, Jeon BH (2001) Ferrous oxidation chemistry in passive abiotic systems for the treatment of mine drainage. Geochem Explor Env Anal 1(1):81-88. https:// doi.org/10.1144/geochem.1.1.81

Dey M, Sadler PJK, Williams KP (2003) A novel approach to mine water treatment. Land Contam Reclamat 11(2):253-258. https:// doi.org/10.2462/09670513.822

Doyle MO, Otte ML (1997) Organism-induced accumulation of iron, zinc and arsenic in wetland soils. Environ Poll 96(1):1-11. https://doi.org/10.1016/S0269-7491(97)00014-6

Droppo IG, Ongley ED (1994) Flocculation of suspended sediment in rivers of southeastern Canada. Water Res 28(8):1799-1809. https://doi.org/10.1016/0043-1354(94)90253-4

Dunbabin JS, Bowmer KH (1992) Potential use of constructed wetlands for treatment of industrial wastewaters containing metals. Sci Total Environ 111(2-3):151-168. https://doi.org/10.1016/00489697(92)90353-T

Elliot AH (2000) Settling of fine sediment in a channel with emergent vegetation. J Hydraul Eng 126(8):570-577. https://doi.org/10. 1061/(ASCE)0733-9429(2000)126:8(570)

Ellis JB, Shutes RB, Revitt DM, Zhang TT (1994) Use of macrophytes for pollution treatment in urban wetlands. Resour Conserv Recy 11(1-4):1-12. https://doi.org/10.1016/0921-3449(94)90074-4

Emerson D, de Vet W (2015) The role of FeOB in engineered water ecosystems: a review. J Am Water Works Ass 107(1):47-57. https://doi.org/10.5942/jawwa.2015.107.0004

Emerson D, Weiss JV, Megonigal JP (1999) Iron-oxidizing bacteria are associated with ferric hydroxide precipitates (Fe-plaque) on the roots of wetland plants. Appl Environ Microb 65(6):2758-2761. https://doi.org/10.1128/AEM.65.6.2758-2761.1999

Ernst (1996) Bioavailability of heavy metals and decontamination of soils by plants. Appl Geochem 11(1-2):163-167. https://doi.org/ 10.1016/0883-2927(95)00040-2

Feierabend JS (1989) Wetlands: the lifeblood of wildlife. In: Hammer DA (ed), Proc, $1^{\text {st }}$ International Conf on Constructed Wetlands for Wastewater Treatment, pp 107-118

Fennessey MS, Mitsch WJ (1989) Treating coal mine drainage with an artificial wetland. Res J Water Pollut C 61(11/12):1691-1701

Fernandes JC, Henriques FS (1990) Metal levels in soils and cattail (Typha latifolia L.) plants in a pyrites mine area at Lousal, Portugal. Int J Environ Stud 36(3):205-210. https://doi.org/10.1080/ 00207239008710597

Galletti A, Verlicchi P, Ranieri E (2010) Removal and accumulation of $\mathrm{Cu}, \mathrm{Ni}$ and $\mathrm{Zn}$ in horizontal subsurface flow constructed wetlands: Contribution of vegetation and filling medium. Sci Total Environ 408(21):5097-5105. https://doi.org/10.1016/j.scitotenv. 2010.07.045

García J, Ojeda E, Sales E, Chico F, Píriz T, Aguirre P, Mujeriego R (2003) Spatial variations of temperature, redox potential, and contaminants in horizontal flow reed beds. Ecol Eng 21(23):129-142. https://doi.org/10.1016/j.ecoleng.2003.10.001

Gearheart RA (1992) Use of constructed wetlands to treat domestic wastewater, city of Arcata. California Water Sci Technol 26(78):1625-1637. https://doi.org/10.2166/wst.1992.0606

Geroni JN, Cravotta CA III, Sapsford DJ (2012) Evolution of the chemistry of Fe bearing waters during $\mathrm{CO} 2$ degassing. Appl Geochem 27(12):2335-2347. https://doi.org/10.1016/j.apgeochem.2012. 07.017

Girts MA, Kleinmann RL, Erickson PM (1987) Performance data on Typha and Sphagnum wetlands constructed to treat coal mine drainage. Proc, 8th Annual West Virginia Surface Mine Drainage Task Force Symp 
Goodarzi D, Lari KS, Alighardashi A (2018) A Large Eddy Simulation study to assess low-speed wind and baffle orientation effects in a water treatment sedimentation basin. Water Sci Technol 2:412421. https://doi.org/10.2166/wst.2018.171

Gu B, Chimney MH, Newman J, Nungesser MK (2006) Limnological characteristics of a subtropical constructed wetland in south Florida (USA). Ecol Eng 27(4):345-360. https://doi.org/10. 1016/j.ecoleng.2006.05.013

Guo C, Cui Y, Dong B, Liu F (2017) Tracer study of the hydraulic performance of constructed wetlands planted with three different aquatic plant species. Ecol Eng 102(1):433-442. https://doi.org/ 10.1016/j.ecoleng.2017.02.040

Hansel CM, Fendorf S, Suttons S, Newville M (2001) Characterization of $\mathrm{Fe}$ plaque and associated metals on the roots of mine-waste impacted aquatic plants. Environ Sci Technol 35(19):3863-3868. https://doi.org/10.1021/es0105459

Hedin RS (2003) Recovery of marketable iron oxide from mine drainage in the USA. Land Contam Reclamat 11(2):93-97. https://doi. org/10.2462/09670513.802

Hedin RS (2008) Iron removal by a passive system treating alkaline coal mine drainage. Mine Water Environ 27(4):200-209. https://doi.org/10.1007/s10230-008-0041-9

Hedin RS (2020) Long-term performance and costs for the Anna $\mathrm{S}$ mine passive treatment systems. Mine Water Environ 39(2):345-355. https://doi.org/10.1007/s10230-020-00676-9

Hedin RS, Narin RW, Kleinmann RLP (1994) Passive treatment of coal mine drainage. US Bureau of Mines, Information Circular 9389

Henrot J, Wieder RK (1990) Processes of iron and manganese retention in laboratory peat microcosms subjected to acid mine drainage. J Environ Qual 19(2):312-320. https://doi.org/10.2134/jeq1990. 00472425001900020018x

Horvath TG (2004) Retention of particulate matter by macrophytes in a first-order stream. Aquat Bot 78(1):27-36. https://doi.org/10. 1016/j.aquabot.2003.09.003

Huntsman RF, Solch JG, Porter MD (1978) Utilization of Sphagnum species dominated bog for coal acid mine drainage abatement. In: Proc, 91st Annual GSA Meeting, Toronto 10(7), 426 pp

Hustwit CC, Ackman TE, Erickson PE (1992) The role of oxygen transfer in acid mine drainage (AMD) treatment. Water Environ Res 64(6):817-823. https://doi.org/10.2175/WER.64.6.10

Ilbert M, Bonnefoy V (2013) Insight into the evolution of the iron oxidation pathways. Biochim Biophys Acta 1827(2):161-175. https://doi.org/10.1016/j.bbabio.2012.10.001

Jadhav RS, Buchberger SG (1995) Effects of vegetation on flow through free water surface wetlands. Ecol Eng 5(4):481-496. https://doi.org/10.1016/0925-8574(95)00039-9

James WF, Barko JW, Butler MG (2004) Shear stress and sediment resuspension in relation to submersed macrophyte biomass. Hydrobiologia 515(1-3):181-191. https://doi.org/10.1023/B:HYDR. $0000027329.67391 . c 6$

Jenkins GA, Greenway M (2005) The hydraulic efficiency of fringing versus banded vegetation in constructed wetlands. Ecol Eng 25(1):61-72. https://doi.org/10.1016/j.ecoleng.2005.03.001

Jing SR, Lin YF, Wang TW, Lee DY (2002) Microcosm wetlands for wastewater treatment with different hydraulic loading rates and macrophytes. J Environ Qual 31(2):690-696. https://doi.org/10. 2134/jeq2002.0690

Johnson DB, Hallberg KB (2002) Pitfalls of passive mine water treatment. Rev Environ Sci Bio 1(4):335-343. https://doi.org/10. 1023/A:1023219300286

Kadlec RH (1994) Detention and mixing in free water wetlands. Ecol Eng 3(4):345-380. https://doi.org/10.1016/0925-8574(94) 00007-7

Kadlec RH (2003) Pond and wetland treatment. Water Sci Technol 48(5):1-8. https://doi.org/10.2166/wst.2003.0266
Kadlec RH, Wallace SD (2009) Treatment wetlands (2nd Edition). CRC Press, $1046 \mathrm{pp}$

Kadlec RH, Knight RL, Vymazal J, Brix H, Cooper P, Haberl R (2000) Constructed wetlands for pollution control: Processes, performance, design and operation. IWA Publishing, Scientific and Technical Report No. 8, $156 \mathrm{pp}$

Kappler A, Emerson D, Gralnick J, Roden E, Muehe EM (2015) Geomicrobiology of iron. Chapter 17 In: Ehrlich's Geomicrobiology (6th Edition), Taylor \& Francis Ltd., 635 pp. https://doi.org/10. 1201/b19121-18

Karathanasis AD, Johnson CM (2003) Metal removal potential by three aquatic plants in an acid mine drainage wetland. Mine Water Environ 22(1):22-30. https://doi.org/10.1007/s102300300004

Khalid S, Shahid M, Niazi KK, Murtaza B, Bibi I, Dumat C (2017) A comparison of technologies for remediation of heavy metal contaminated soils. J Geochem Explor 182(B):247-268. https:// doi.org/10.1016/j.gexplo.2016.11.021

Kirby CS, Thomas HM, Southam G, Donald R (1999) Relative contributions of abiotic and biological factors in Fe(II) oxidation in mine drainage. Appl Geochem 14(4):511-530. https://doi.org/ 10.1016/S0883-2927(98)00071-7

Kleinmann RL, Tiernan TO, Solch JG, Harris RL (1983) A low-cost, low-maintenance treatment system for acid mine drainage using Sphagnum moss and limestone. In: Graves DH (ed), Proc, 1983 Symp on Surface Mining, Hydrology, Sedimentology, and Reclamation, Lexington, pp 241-245

Knight RL (1997) Wildlife habitat and public use benefits of treatment wetlands. Water Sci Technol 35(5):35-43. https://doi.org/ 10.1016/S0273-1223(97)00050-4

Knight RL, Clarke RA Jr, Bastian RK (2001) Surface flow (sf) treatment wetlands as a habitat for wildlife and humans. Water Sci Technol 44(11-12):27-38. https://doi.org/10.2166/wst.2001. 0806

Koren DW, Gould WD, Bédard P (2000) Biological removal of ammonia and nitrate from simulated mine and mill effluents. Hydrometallurgy 56(2):127-144. https://doi.org/10.1016/S0304386X(99)00088-2

Kruse NA, Gozzard E, Jarvis AP (2009) Determination of hydraulic residence times in several UK mine water treatment systems and their relationship to iron removal. Mine Water Environ 28(2):115-123. https://doi.org/10.1007/s10230-009-0068-6

Kuehn E, Moore JA (1995) Variability of treatment performance in constructed wetlands. Water Sci Technol 32(3):241-250. https:// doi.org/10.1016/0273-1223(95)00625-7

Kumari M, Tripathi BD (2015) Efficiency of Phragmites australis and Typha latifolia for heavy metal removal from wastewater. Ecotox Environ Safe 112(1):80-86. https://doi.org/10.1016/j.ecoenv. 2014.10.034

Kusin FM, Jarvis AP, Gandy CJ (2010) Hydraulic residence time and iron removal in a wetland receiving ferruginous mine water over a 4 year period from commissioning. Water Sci Technol 62(8):937-946. https://doi.org/10.2166/wst.2010.495

Lacki MJ, Hummer JW, Webster HJ (1992) Mine-drainage treatment wetland as habitat for herpetofaunal wildlife. Environ Manage 16(4):513-520. https://doi.org/10.1007/BF02394127

Laine DM, Jarvis AP (2003) Engineering design aspects of passive in situ remediation of mining effluents. Land Contam Reclamat 11(2):113-125. https://doi.org/10.2462/09670513.805

Larsen VJ, Schierup HH (1981) Macophyte cycling of zinc, copper, lead and cadmium in the littoral zone of a polluted and a nonpolluted lake. II. Seasonal changes in heavy metal content of above-ground biomass and decomposing leaves of Phragmites australis (Cav.) Trin. Aquat Bot 11(1):211-230. https://doi.org/ 10.1016/0304-3770(81)90062-0

Laurent J, Bois P, Nuel M, Wanko A (2015) Systemic models of full-scale surface flow treatment wetlands: determination by 
application of fluorescent tracers. Chem Eng J 264(1):389-398. https://doi.org/10.1016/j.cej.2014.11.073

Lesage E, Mundia C, Rousseau DP, van de Moorte AM, du Laing G, Meers E, Tack FM, de Pauw M, Verloo MG (2007) Sorption of $\mathrm{Co}, \mathrm{Cu}, \mathrm{Ni}$ and $\mathrm{Zn}$ from industrial effluents by the submerged aquatic macrophyte Myriophyllum spicatum L. Ecol Eng 30(4):320-325. https://doi.org/10.1016/j.ecoleng.2007.04.007

Liang L, McNabb JA, Paulk JM, Gu B, McCarthy JF (1993) Kinetics of $\mathrm{Fe}(\mathrm{II})$ oxygenation at low partial pressures of oxygen in the presence of natural organic matter. Environ Sci Technol 27(9):18641870. https://doi.org/10.1021/es00046a014

Liquete C, Udias A, Conte G, Grizzetti B, Masi F (2016) Integrated valuation of a nature-based solution for water pollution control. Highlighting hidden benefits. Ecosyst Serv 22(B):392-401. https://doi.org/10.1016/j.ecoser.2016.09.011

Liu J, Dong Y, Xu H, Wang D, Xu J (2007) Accumulation of Cd, Pb and $\mathrm{Zn}$ by 19 wetland plant species in constructed wetlands. $\mathrm{J}$ Hazard Mater 147(3):947-953. https://doi.org/10.1016/j.jhazm at.2007.01.125

Luan F, Santelli CM, Hansel CM, Burgos WD (2012) Defining manganese(II) removal processes in passive coal mine drainage treatment systems through laboratory incubation experiments. Appl Geochem 27(8):1567-1578. https://doi.org/10.1016/j.apgeo chem.2012.03.010

Maine MA, Suñe N, Hadad H, Sánchez G, Bonetto C (2006) Nutrient and metal removal in a constructed wetland for wastewater treatment from a metallurgic industry. Ecol Eng 26(4):341-347. https://doi.org/10.1016/j.ecoleng.2005.12.004

Maine MA, Suñe N, Hadad H, Sánchez G, Bonetto C (2009) Influence of vegetation on the removal of heavy metals and nutrients in a constructed wetland. J Environ Manage 90(1):355-363. https:// doi.org/10.1016/j.jenvman.2007.10.004

Makhathini TP, Mulopo J, Bakare BF (2020) Possibilities for acid mine drainage co-treatment with other waste streams: a review. Mine Water Environ 39(1):13-26. https://doi.org/10.1007/ s10230-020-00659-w

Manios T, Stentiford EI, Millner PA (2003) The effect of heavy metals accumulation on the chlorophyll concentration of Typha latifolia plants, growing in a substrate containing sewage sludge compost and watered with metalliferous water. Ecol Eng 20(1):65-74. https://doi.org/10.1016/S0925-8574(03)00004-1

Marchand L, Mench M, Jacob DL, Otte ML (2010) Metal and metalloid removal in constructed wetlands, with emphasis on the importance of plants and standardized measurements: a review. Environ Pollut 158(12):3447-3461. https://doi.org/10.1016/j. envpol.2010.08.018

Masi F, Rizzo A, Regelsberger M (2018) The role of constructed wetlands in a new circular economy, resource oriented, and ecosystem services paradigm. J Environ Manage 216(1):275-284. https://doi.org/10.1016/j.jenvman.2017.11.086

Matthews DJ, Moran BM, Otte ML (2004) Zinc tolerance, uptake, and accumulation in the wetland plants Eriophorum angustifolium, Juncus effusus, and Juncus articulates. Wetlands 24(4):859-869. https://doi.org/10.1672/0277-5212(2004)024[0859:ZTUAAI]2.0. $\mathrm{CO} ; 2$

Mayer LM (1982) Aggregation of colloidal iron during estuarine mixing: kinetics, mechanism, and seasonality. Geochim Cosmochim Acta 46(12):2527-2535. https://doi.org/10.1016/0016-7037(82) 90375-1

Mayes WM, Batty LC, Younger PL, Jarvis AP, Kõiv M, Vohla C, Mander U (2009) Wetland treatment at extremes of $\mathrm{pH}$ : a review. Sci Total Environ 407(13):3944-3957. https://doi.org/10.1016/j. scitotenv.2008.06.045

Mays WM, Edwards GS (2001) Comparison of heavy metal accumulation in a natural wetland and constructed wetlands receiving acid mine drainage. Ecol Eng 16(4):487-500. https://doi.org/10.1016/ S0925-8574(00)00112-9

McInnes R (2013) Recognising wetland ecosystem services within urban case studies. Mar Freshwater Res 65(7):575-588. https:// doi.org/10.1071/MF13006

McIntire PE, Edenborn HM (1990) The use of bacterial sulfate reduction in the treatment of drainage from coal mines. In: Skousen J, Sencindiver J, Samuel D (eds), Proc, 1990 Mining and Reclamation Conf, Charleston, pp 409-415

Mitsch WJ, Wise KM (1998) Water quality, fate of metals, and predictive model validation of a constructed wetland treating acid mine drainage. Water Res 32(6):1888-1900. https://doi.org/10.1016/ S0043-1354(97)00401-6

Mitsch WJ, Zhang L, Stefanik KC, Nahlik AM, Anderson CJ, Bernal B, Hernandez M, Song K (2012) Creating wetlands: primary succession, water quality changes, and self-design over 15 years. Bioscience 62(3):237-250. https://doi.org/10.1525/bio.2012. 62.3 .5

Mitsch WJ, Zhang L, Waletzko E, Bernal B (2014) Validation of the ecosystem services of created wetlands: two decades of plant succession, nutrient retention, and carbon sequestration in experimental riverine marshes. Ecol Eng 72:11-24. https:// doi.org/10.1016/j.ecoleng.2014.09.108

Mouchet P (1992) From conventional to biological removal of iron and manganese in France. J Am Water Works Ass 84(4):158167. https://doi.org/10.1002/j.1551-8833.1992.tb07342.x

Nepf HM (1999) Drag, turbulence, and diffusion in flow through emergent vegetation. Water Resour Res 35(2):479-489. https:// doi.org/10.1029/1998WR900069

Neubauer SC, Emerson D, Megonigal JP (2002) Life at the energetic edge: Kinetics of circumneutral iron oxidation by lithotrophic iron-oxidizing bacteria isolated from the wetland-plant rhizosphere. Appl Environ Microb 68(8):3988-3995. https://doi.org/ 10.1128/AEM.68.8.3988-3995.2002

Nixdorf B, Fyson A, Krumbeck H (2001) Review: plant life in extremely acidic waters. Environ Exp Bot 46(3):203-211. https://doi.org/10.1016/S0098-8472(01)00104-6

Noller BN, Woods PH, Ross BJ (1994) Case studies of wetland filtration of mine waste water in constructed and naturally occurring systems in Northern Australia. Water Sci Technol 29(4):257265. https://doi.org/10.2166/wst.1994.0205

Noller BN, Parker GK, Gao GH (2003) Metal and solute transportation through a wetland at a Lead Zinc Mine, Northern Territory, Australia. Eur J Miner Process Environ Prot 3(1):15-35

Nuttal CA (2003) Testing and performance of a newly constructed full-scale passive treatment system at Whittle Colliery, Northumberland. Land Contam Reclamat 11(2):105-112. https://doi. org/10.2462/09670513.804

Nyquist J, Greger M (2009) A field study of constructed wetlands for preventing and treating acid mine drainage. Ecol Eng 35(5):630-642. https://doi.org/10.1016/j.ecoleng.2008.10.018

O'Sullivan AD, Moran BM, Otte ML (2004) Accumulation and fate of contaminants $(\mathrm{Zn}, \mathrm{Pb}, \mathrm{Fe}$ and $\mathrm{S})$ in substrates of wetlands constructed for treating mine wastewater. Water Air Soil Poll 157(1-4):345-364. https://doi.org/10.1023/B:WATE.00000 38882.09628.ab

Opitz J, Alte M, Bauer M, Peiffer S (2019) Testing iron removal in a trifurcated pilot plant for passive treatment of circumneutral ferruginous mine water. In: Khayrulina E, Wolkersdorfer C, Polyakova S, Bogush A (eds.) Proc, IMWA Conf, Perm, pp 256-261

Opitz J, Alte M, Bauer M, Peiffer S (2020) Quantifying iron removal efficiency of a passive mine water treatment system using turbidity as a proxy for (particulate) iron. Appl Geochem 122:104731. https://doi.org/10.1016/j.apgeochem.2020.104731 
Outridge PM, Noller BN (1991) Accumulation of toxic trace elements by freshwater vascular plants. Rev Environ Contam T 121:1-63. https://doi.org/10.1007/978-1-4612-3196-7_1

Overall RA, Parry DL (2004) The uptake of uranium by Eleocharis dulcis (Chinese water chestnut) in the Ranger Uranium Mine constructed wetland filter. Environ Pollut 132(2):307-320. https:// doi.org/10.1016/j.envpol.2004.04.005

Parker K (2003) Mine water management on a national scaleexperiences from the Coal Authority. Land Contam Reclamat 11(2):181-190. https://doi.org/10.2462/09670513.813

Pedescoll A, Sidrach-Cardona R, Hijosa-Valsero M, Bécares E (2015) Design parameters affecting metals removal in horizontal constructed wetlands for domestic wastewater treatment. Ecol Eng 80(1):92-99. https://doi.org/10.1016/j.ecoleng.2014.10.035

Peiffer S, Walton-Day K, Macalady DL (1999) The interaction of natural organic matter with iron in a wetland (Tennessee Park, Colorado) receiving acid mine drainage. Aquat Geochem 5(2):207233. https://doi.org/10.1023/A:1009617925959

Persson J, Wittgren HB (2003) How hydrological and hydraulic conditions affect performance of ponds. Ecol Eng 21(4-5):259-269. https://doi.org/10.1016/j.ecoleng.2003.12.004

Persson J, Somes NL, Wong TH (1999) Hydraulics efficiency of constructed wetlands and ponds. Water Sci Technol 40(3):291-300. https://doi.org/10.1016/S0273-1223(99)00448-5

Pietrangelo L, Bucci A, Maiuro L, Bulgarelli D, Naclerio G (2018) Unraveling the composition of the root-associated bacterial microbiota of Phragmites australis and Typha latifolia. Front Microbiol 9:1650. https://doi.org/10.3389/fmicb.2018.01650

Pizarro J, Belzile N, Filella M, Leppard GG, Negre JC, Perret D, Buffle $\mathrm{J}$ (1995) Coagulation/sedimentation of submicron iron particles in a eutrophic lake. Water Res 29(2):617-632. https://doi.org/10. 1016/0043-1354(94)00167-6

Pluntke T, Kozerski HP (2003) Particle trapping on leaves and on the bottom in simulated submerged plant stands. Hydrobiologia 506(1-3):575-581. https://doi.org/10.1023/B:HYDR.00000 08569.29286.ec

Saiers JE, Harvey JW, Mylon SE (2003) Surface-water transport of suspended matter through wetland vegetation of the Florida everglades. Geophys Res Lett. https://doi.org/10.1029/2003G L018132

Samsó R, García J (2013) Bacteria distribution and dynamics in constructed wetlands based on modelling results. Sci Total Environ 461-462:430-440. https://doi.org/10.1016/j.scitotenv.2013.04. 073

Sapsford DJ (2013) New perspectives on the passive treatment of ferruginous circumneutral mine waters in the UK. Environ Sci Pollut R 20:7827-7836. https://doi.org/10.1007/s11356-013-1737-3

Sapsford DJ, Watson I (2011) A process-orientated design and performance assessment methodology for passive mine water treatment systems. Ecol Eng 37(6):970-975. https://doi.org/10.1016/j.ecole ng.2010.12.010

Sapsford DJ, Santonastaso M, Thorn P, Kershaw S (2015) Conversion of coal mine drainage ochre to water treatment reagent: production, characterisation and application for $\mathrm{P}$ and $\mathrm{Zn}$ removal. $\mathrm{J}$ Environ Manage 160(1):7-15. https://doi.org/10.1016/j.jenvm an.2015.06.004

Schierup HH, Larsen VJ (1981) Macrophyte cycling of zinc, copper, lead and cadmium in the littoral zone of a polluted and a nonpolluted lake. I. Availability, uptake and translocation of heavy metals in Phragmites australis (Cav.) Trin. Aquat Bot 11(1):197210. https://doi.org/10.1016/0304-3770(81)90061-9

Schmid BH, Stephan U, Hengl MA (2005) Sediment deposition in constructed wetland ponds with emergent vegetation: laboratory study and mathematical model. Water Sci Technol 51(9):307314. https://doi.org/10.2166/wst.2005.0342
Scholes L, Shutes RB, Revitt DM, Forshaw M, Purchase D (1998) The treatment of metals in urban runoff by constructed wetlands. Sci Total Environ 214(1-3):211-219. https://doi.org/10.1016/S00489697(98)00072-2

Seidel K (1966) Reinigung von Gewässern durch höhere Pflanzen [Water treatment by higher plants]. Naturwissenschaften 53(12):289-297. https://doi.org/10.1007/BF00712211

Sencindiver JC, Bhumbla DK (1988) Effects of cattails (Typha) on metal removal from mine drainage. In: Proc, 1988 Mine Drainage and Surface Mine Reclamation Conf, US Bureau of Mines Information Circular 9184, Volume 1: Mine Water and Mine Waste. 359-366. https://doi.org/10.21000/JASMR88010359

Sheoran AS, Sheoran V (2006) Heavy metal removal mechanism of acid mine drainage in wetlands: a critical review. Miner Eng 19(2):105-116. https://doi.org/10.1016/j.mineng.2005.08.006

Sholkovitz ER (1978) The flocculation of dissolved $\mathrm{Fe}, \mathrm{Mn}, \mathrm{Al}, \mathrm{Cu}$, $\mathrm{Ni}, \mathrm{Co}$ and $\mathrm{Cd}$ during estuarine mixing. Earth Planet Sc Lett 41(1):77-86. https://doi.org/10.1016/0012-821X(78)90043-2

Skousen J, Zipper CE, Rose A, Ziemkiewicz PF, Narin R, McDonald LM, Kleinmann RL (2017) Review of passive systems for acid mine drainage treatment. Mine Water Environ 36(1):133-153. https://doi.org/10.1007/s10230-016-0417-1

Snoddy EL, Brodie GA, Hammer DA, Tomljanovich DA (1989) Control of the armyworm, Simyra Henrici, on cattail plantings in acid mine drainage treatment wetlands at Widows Creek steamelectric plant. In: Hammer DA (ed) Constructed wetlands for wastewater treatment: Municipal, industrial, and agricultural, 808-811

Snowden RE, Wheeler BD (1995) Chemical changes in selected wetland plant species with increasing Fe supply, with specific reference to root precipitates and Fe tolerance. New Phytol 131(4):503-520. https://doi.org/10.1111/j.1469-8137.1995. tb03087.x

Sobolev D, Roden EE (2001) Suboxic deposition of ferric iron by bacteria in opposing gradients of $\mathrm{Fe}(\mathrm{II})$ and oxygen at circumneutral pH. Appl Environ Microb 67(3):1328-1334. https:// doi.org/10.1128/AEM.67.3.1328-1334.2001

Sobolewski A (1999) A review of processes responsible for metal removal in wetlands treating contaminated mine drainage. Int J Phytoremediat 1(1):19-51. https://doi.org/10.1080/15226 519908500003

Stark LR, Kolbash RL, Webster HJ, Stevens SE, Dionis KA, Murphy ER (1988) The Simco\#4 wetland: Biological patterns and performance. In: Mine Drainage and Surface Mine Reclamation, Vol. I: Mine Water and Mine Waste, US Bureau of Mines IC9183, 332-344. https://doi.org/10.21000/JASMR88010332

Stark LR, Williams FR, Stevens Jr. SE, Eddy DP (1994) Iron retention and vegetative cover at the Simco constructed wetland: An appraisal through year eight of operation. In: Proc, International Land Reclamation and Mine Drainage Conf and 3rd International Conf on the Abatement of Acidic Drainage, Pittsburgh

Stark LR, Williams FM, Wenerick WR, Wuest PJ, Urban C (1996) The effects of substrate type, surface water depth, and flow rate on manganese retention in mesocosm wetlands. J Environ Qual 25(1):97-106. https://doi.org/10.2134/jeq1996.0047242500 2500010013x

St-Cyr L, Campbell PG (1996) Metals (Fe, Mn, Zn) in the root plaque of submerged aquatic plants collected in situ: relations with metal concentrations in the adjacent sediments and in the root tissue. Biogeochemistry 33(1):45-76. https://doi.org/10.1007/BF000 00969

Stumm W, Morgan JJ (1996) Aquatic chemistry-chemical equilibria and rates in natural waters (3rd Ed.) John Wiley \& Sons, 1019 pp

Su TM, Yang SC, Shih SS, Lee HY (2009) Optimal design for hydraulic efficiency performance of free-water-surface constructed 
wetlands. Ecol Eng 35(8):1200-1207. https://doi.org/10.1016/j. ecoleng.2009.03.024

Tanner CC (1996) Plants for constructed wetland treatment systems-a comparison of the growth and nutrient uptake of eight emergent species. Ecol Eng 7(1):59-83. https://doi.org/10.1016/09258574(95)00066-6

Taylor GJ, Crowder AA (1981) Uptake and accumulation of heavy metals by Typha latifolia in wetlands of the Sudbury. Ontario region Can J Botany 61(1):63-73. https://doi.org/10.1139/b83-005

Taylor GJ, Crowder AA (1983) Uptake and accumulation of copper, nickel, and iron by Typha latifolia grown in solution culture. Can J Botany 61(7):1825-1830. https://doi.org/10.1139/b83-193

Thackston EL, Shields FD, Schroeder PR (1987) Residence time distributions of shallow basins. J Environ Eng 113(6):1319-1332. https://doi.org/10.1061/(ASCE)0733-9372(1987)113:6(1319)

Thullen JS, Sartoris JJ, Nelson SM (2005) Managing vegetation in surface-flow wastewater-treatment wetlands for optimal treatment performance. Ecol Eng 25(5):583-593. https://doi.org/10. 1016/j.ecoleng.2005.07.013

Tipping E, Cooke D (1982) The effects of adsorbed humic substances on the surface charge of goethite $(\alpha-\mathrm{FeOOH})$ in freshwaters. Geochim Cosmochim Acta 46(1):75-80. https://doi.org/10.1016/ 0016-7037(82)90292-7

Tipping E, Hurley MA (1992) A unifying model of cation binding by humic substances. Geochim Cosmochim Acta 56(10):36273641. https://doi.org/10.1016/0016-7037(92)90158-F

Tipping E, Ohnstad M (1984) Colloid stability of iron oxide particles from a freshwater lake. Nature 308(5956):266-268. https://doi. org/10.1038/308266a0

Tuhela L, Carlson L, Tuovinen OH (1992) Ferrihydrite in water wells and bacterial enrichment cultures. Water Res 26(9):1159-1162. https://doi.org/10.1016/0043-1354(92)90175-4

van der Beek CG, Hiemstra T, Hofs B, Nederlof MM, van Paassen JA, Reijnen GK (2012) Homogeneous, heterogeneous and biological oxidation of iron(II) in rapid sand filtration. J Water Supply Res T 61(1):1-13. https://doi.org/10.2166/aqua.2012.033

Verschoren V, Schoelynck J, Cox T, Schoutens K, Temmerman S, Meire P (2017) Opposing effects of aquatic vegetation on hydraulic functioning and transport of dissolved and organic particulate matter in a lowland river: a field experiment. Ecol Eng 105(1):221-230. https://doi.org/10.1016/j.ecoleng.2017.04.064

Vymazal J (2013) The use of hybrid constructed wetlands for wastewater treatment with special attention to nitrogen removal: a review of a recent development. Water Res 47(14):4795-4811. https:// doi.org/10.1016/j.watres.2013.05.029

Vymazal J (2014) Constructed wetlands for treatment of industrial wastewaters: a review. Ecol Eng 73(1):724-751. https://doi.org/ 10.1016/j.ecoleng.2014.09.034

Wahl MD, Brown LC, Soboyejo AO, Dong B (2012) Quantifying the hydraulic performance of treatment wetlands using reliability functions. Ecol Eng 47(1):120-125. https://doi.org/10.1016/j. ecoleng.2012.06.009

Walton-Day K (1997) Geochemistry of the processes that attenuate acid mine drainage in wetlands. Rev Econ Geol 6A:215-228. https://doi.org/10.5382/Rev.06.10

Watson J, Sherwood SC, Kadlec RH, Knight R, Whitehouse R (1989) Performance expectations and loading rates for constructed wetlands. In: Constructed Wetlands for Wastewater Treatment: Municipal, Industrial, and Agricultural, Lewis Publishers, pp 319-352

Weber KA, Achenbach LA, Coates JD (2006) Microorganisms pumping iron: anaerobic microbial iron oxidation and reduction. Nat
Rev Microbiol 4(10):752-764. https://doi.org/10.1038/nrmic ro1490

Weiss JV, Emerson D, Backer SM, Megonigal JP (2003) Enumeration of $\mathrm{Fe}$ (II)-oxidizing and $\mathrm{Fe}(\mathrm{III})$-reducing bacteria in the root zone of wetland plants: implications for a rhizosphere iron cycle. Biogeochemistry 64(1):77-96. https://doi.org/10.1023/A:10249 53027726

Wenerick WR, Stevens SE, Webster HJ, Stark LR, DeVeau E (1989) Tolerance of three wetlands plant species to acid mine drainage: a greenhouse study. In: Hammer DA (ed.) Constructed Wetlands for Wastewater Treatment: Municipal, Industrial, and Agricultural, 801-807

Wieder RK (1989) A survey of constructed wetlands for acid coal mine drainage treatment in the eastern United States. Wetlands 9(2):299-315. https://doi.org/10.1007/BF03160750

Wieder RK, Lang GE, Whitehouse AE (1982) Modification of acid mine drainage in a freshwater wetland. In: Behling RE (ed.), Proc, Symp on Wetlands of the Unglaciated Appalachian Region, pp 43-53

Wildemann T, Brodie G, Gusek J (1993) Wetland Design for Mining Operations. BiTech Publishers Ltd

Wittgren HB, Maehlum T (1997) Wastewater treatment wetlands in cold climates. Water Sci Technol 35(5):45-53. https://doi.org/ 10.1016/S0273-1223(97)00051-6

Wu H, Zhank J, Ngo HH, Guo W, Hu Z, Liang S, Fan J, Liu H (2015) A review on the sustainability of constructed wetlands for wastewater treatment: Design and operation. Bioresource Technol 175(1):594-601. https://doi.org/10.1016/j.biortech.2014.10.068

Yang B, Lan CY, Yang CS, Liao WB, Chang H, Shu WS (2006) Longterm efficiency and stability of wetlands for treating wastewater of a lead/zinc mine and the concurrent ecosystem development. Environ Pollut 143(3):499-512. https://doi.org/10.1016/j.envpol. 2005.11.045

Ye ZH, Baker JM, Wong MH, Willis AJ (1997a) Copper and nickel uptake, accumulation and tolerance in Typha latifolia with and without iron plaque on the root surface. New Phytol 136(3):481488. https://doi.org/10.1046/j.1469-8137.1997.00758.x

Ye ZH, Baker JM, Wong MH, Willis AJ (1997b) Zinc, lead and cadmium tolerance, uptake and accumulation by Typha latifolia. New Phytol 136(3):469-480. https://doi.org/10.1046/j.14698137.1997.00759.x

Ye ZH, Cheung KC, Wong MH (2001a) Copper uptake in Typha latifolia as affected by iron and manganese plaque on the root surface. Can J Botany 79(3):314-320. https://doi.org/10.1139/b01-012

Ye ZH, Whiting SN, Lin ZQ, Lytle CM, Qian JH, Terry N (2001b) Removal and distribution of iron, manganese, cobalt, and nickel within a Pennsylvania constructed wetland treating coal combustion by-product leachate. J Environ Qual 30(4):1464-1473. https://doi.org/10.2134/jeq2001.3041464x

Ye ZH, Whiting SN, Qian JH, Lytle CM, Lin ZQ, Terry N (2001c) Trace element removal from coal ash leachate by a 10 -year-old constructed wetland. J Environ Qual 30(5):1710-1719. https:// doi.org/10.2134/jeq2001.3051710x

Younger PL, Banwart SA, Hedin RS (2002) Mine water-hydrology, pollution, remediation. Springer Science, https://doi.org/10.1007/ 978-94-010-0610-1

Zaitsev G, Mettänen T, Langwaldt J (2008) Removal of ammonium and nitrate from cold inorganic mine water by fixed-bed biofilm reactors. Miner Eng 21(1):10-15. https://doi.org/10.1016/j.mineng. 2007.08.014 